\title{
Upper Oligocene (Chattian) brachiopod fauna from the Aquitaine Basin, southwestern France and its paleoenvironmental implications
}

\author{
Maria Aleksandra BITNER \\ Institute of Paleobiology, Polish Academy of Sciences, \\ ul. Twarda 51/55, 00-818 Warszawa (Poland) \\ bitner@twarda.pan.pl \\ Pierre LOZOUET \\ Muséum national d'Histoire naturelle, \\ case postale 51, 57 rue Cuvier, F-75231 Paris cedex 05 (France) \\ lozouet@mnhn.fr \\ Bruno CAHUZAC \\ Université Bordeaux-1, \\ Laboratoire de Recherches et Applications géologiques, \\ Château-Bonnefont, 351, cours de la Libération, \\ F-33405 Talence cedex (France) \\ b.cahuzac@ufr-termer.u-bordeaux1.fr
}

Bitner M. A., Lozouet P. \& Cahuzac B. 2013. - Upper Oligocene (Chattian) brachiopod fauna from the Aquitaine Basin, southwestern France and its paleoenvironmental implications. Geodiversitas 35 (3): 579-606. http://dx.doi.org/10.5252/g2013n3a4

KEY WORDS

Brachiopoda, Upper Oligocene,

Chattian,

stable isotopes,

Aquitaine Basin,

France,

new species.

\section{ABSTRACT}

Brachiopods from the Upper Oligocene (Chattian), Aquitaine Basin, southwestern France comprise nine species in seven genera: Novocrania Lee \& Brunton, 2001, Terebratulina d'Orbigny, 1847, Megathiris d'Orbigny, 1847, Argyrotheca Dall, 1900, Joania Álvarez, Brunton \& Long, 2008, Megerlia King, 1850, and Lacazella Munier-Chalmas, 1880 . One megathyridid is described as a new species, Joania peyrerensis n. sp., characterized by ornamentation of 6-8 distinct, sharp ribs and by triangular, plate-like teeth. With the exception of Megathiris detruncata (Gmelin, 1791) and Lacazella mediterranea (Risso, 1826), all species are recorded for the first time from the Oligocene of the Aquitaine Basin. In taxonomic composition this brachiopod fauna displays close affinity with the Miocene faunas of the Mediterranean Province and Central Paratethys. The dominance of micromorphic megathyridids and thecideides in the Peyrère assemblage, characteristic of cryptic habitats suggests the presence of submarine caves and/or crevices, thus supporting the previous interpretations of this faunistic assemblage as a cave biocenosis. Frequency of gastropod drillings observed on the investigated brachiopods is low $(4 \%)$ as is in most Cenozoic brachiopod populations. The paleotemperatures calculated from the $\delta 18 \mathrm{O}$ values of brachiopod shells $\left(21\right.$ to $\left.24^{\circ} \mathrm{C}\right)$ correspond well to a paleoenvironmental interpretation based on paleoecology of other taxonomic groups. 


\section{MOTS CLÉS \\ Brachiopoda, \\ Oligocène supérieur, Chattien, \\ isotopes stables, Bassin d'Aquitaine, France, espèce nouvelle.}

\begin{abstract}
RÉSUMÉ
La faune de brachiopodes de l'Oligocène supérieur (Chattien) du Bassin d'Aquitaine, sud-ouest de la France et ses implications paléoenvironnementales.

Les brachiopodes de l'Oligocène supérieur (Chattien) du Bassin d'Aquitaine (France) comprennent neuf espèces appartenant à sept genres, à savoir Novocrania Lee \& Brunton, 2001, Terebratulina d'Orbigny, 1847, Megathiris d'Orbigny, 1847, Argyrotheca Dall, 1900, Joania Álvarez, Brunton \& Long, 2008, Megerlia King, 1850 et Lacazella Munier-Chalmas, 1880. Un Megathyrididae nouveau est décrit : Joania peyrerensis $\mathrm{n}$. sp. Cette espèce est caractérisée par une ornementation comprenant de six à huit côtes fortes et aiguës, et par des dents triangulaires ressemblant à des plaques. À l'exception de Megathiris detruncata (Gmelin, 1791) et de Lacazella mediterranea (Risso, 1826), toutes les espèces sont signalées pour la première fois dans l'Oligocène aquitain. Dans sa composition taxonomique, cette faune de brachiopodes présente des affinités étroites avec celles du Miocène de la province méditerranéenne et de la Paratéthys centrale. La domination des Megathyrididae micromorphiques et Thecideidae à Peyrère, caractéristiques des habitats cryptiques, indique la présence de nombreuses grottes sous-marines et/ou de crevasses, appuyant ainsi les interprétations précédentes sur l'environnement de ces dépôts. La fréquence de la prédation de gastéropodes observée sur les brachiopodes étudiés est basse (4\%) comme elle l'est dans la plupart des populations de brachiopodes cénozoïques. Les paléotempératures calculées des valeurs $\delta 18 \mathrm{O}$ obtenues des coquilles de brachiopodes (de 21 à $24^{\circ} \mathrm{C}$ ) correspondent bien à l'interprétation paléoenvironnementale basée sur la paléoécologie des autres groupes.
\end{abstract}

\section{INTRODUCTION}

Although brachiopods have lost importance in the Cenozoic and their taxonomic diversity is low, they are a stable, locally even dominant, element of the benthic fauna in European Tertiary deposits. Eocene brachiopods are well known and described from the whole of Europe, and although their taxonomic composition in particular assemblages can differ significantly, many species have a very wide geographical distribution from Great Britain to Ukraine. Miocene brachiopods are also well known in the whole of Europe, being especially studied from the Paratethyan and Mediterranean provinces, and they are predominantly micromorphic forms.

By contrast, very little is known about Oligocene brachiopods of Europe. They have been reported from northern Italy (Sacco 1902; Fabiani 1913; Venzo 1941; Mandruzzato 1970; Altichieri 1992) where Terebratula Müller, 1776, Terebratulina d'Orbigny, 1847 and Lacazella Munier-Chalmas, 1880 were recorded. Terebratulina was also reported from the Oligocene of Belgium (Vincent 1893, 1923). Sandberger (1862-1863) described a rich brachiopod fauna from the Lower Oligocene of the Mainz Basin, southern Germany. He recognized Terebratula, Terebratulina and few species of megathyridid brachiopods. This fauna, however, needs reexamination and re-description using modern taxonomy; one species, Argiope subradiata Sandberger, 1862 has been revised and transferred into the genus Bronnothyris Popiel-Barczyk \& Smirnova, 1978 (see Bitner \& Kroh 2011). The 


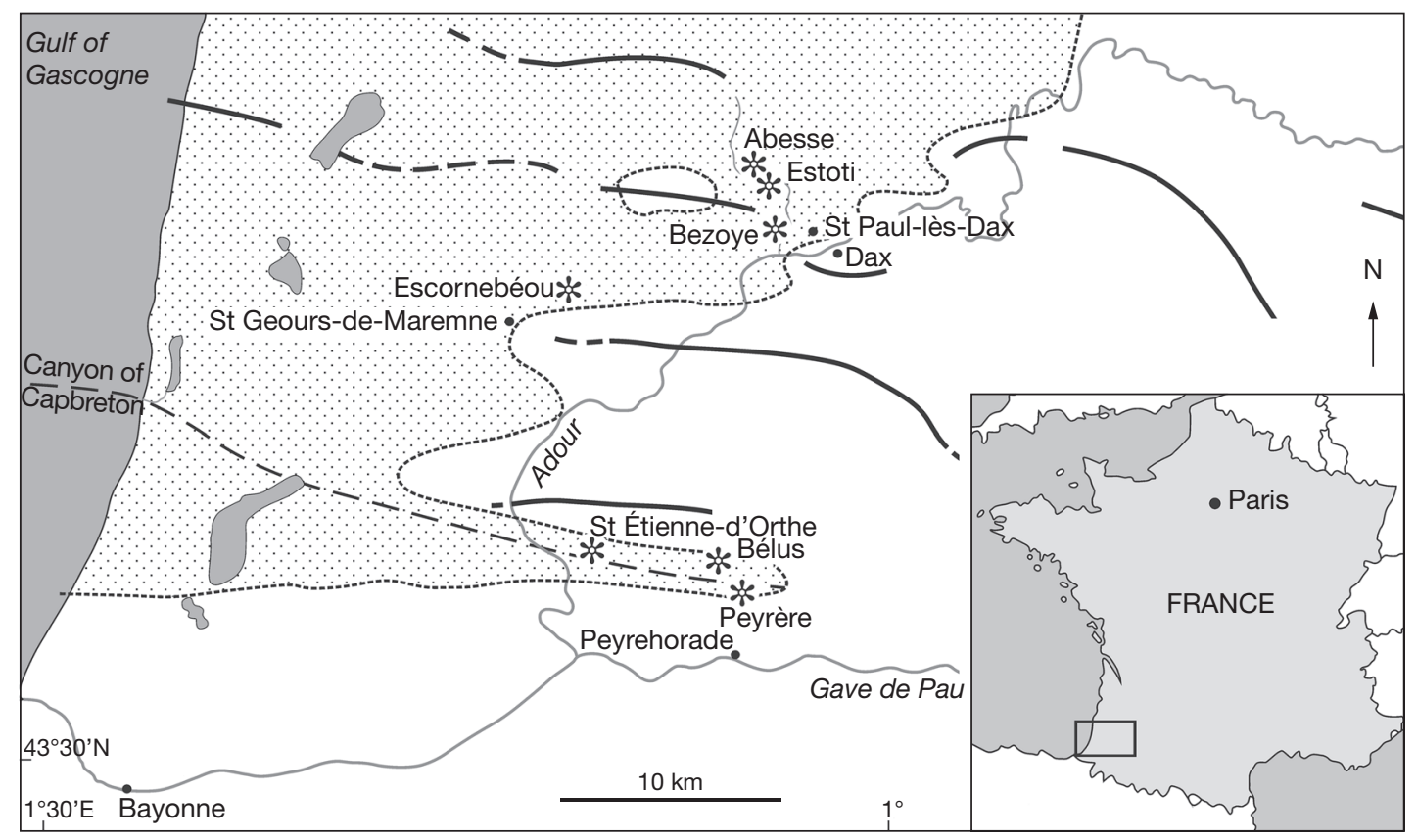

FIG. 1. - Map of the Aquitaine Basin, SW France showing the extension of the Chattian marine deposits (dotted line) and the localities of brachiopod fauna; heavy lines denote anticlinal ridges (simplified after Cahuzac et al. 1995).

inarticulate discinid species Discinisca steiningeri Radwańska \& Radwański, 1989 was described from the Upper Oligocene of Austria (Radwańska \& Radwański 1989).

From the Oligocene of Hungary Meznerics (1944) described three genera, Lingula Bruguière, 1797, Terebratula and Terebratulina. Recently, a rich collection of Oligocene brachiopods from Hungary was also reported by Dulai (2010b). He recognized ten species belonging to nine genera; megathyrids dominate but Novocrania Lee \& Brunton, 2001, Gryphus Mühlfeldt, 1811, Terebratulina and Megerlia King, 1850 also were present.

A new Lower Oligocene brachiopod fauna was briefly described from north-eastern Germany (Müller 2011a, b). This fauna contains one inarticulate genus, Discinisca, six terebratulides, Terebratula, Terebratulina, Orthothyris Cooper, 1955, Megathiris d'Orbigny, 1847, Argyrotheca Dall, 1900 and Megerlia, and the thecideide Lacazella.
It is worth mentioning that the brachiopod assemblage from northern Germany described as Lower Oligocene by von Koenen (1894) has been found to be Upper Eocene in age (see De Geyter et al. 2006).

The present paper deals with a rich Upper Oligocene (Chattian) brachiopod fauna from the Aquitaine Basin (SW France) that belongs to the Atlantic Province. Brachiopods, in majority excellently preserved, with more than 1400 specimens are represented by nine species belonging to seven genera. Although so rich, this fauna has never been fully described before, however, the presence of the genera Megathiris, Argyrotheca and Lacazella was mentioned by several researchers (Peyrot 1932; Pajaud 1974; Lozouet 2004). Interestingly, brachiopods were described from the Aquitaine Basin from the younger, Miocene, deposits where inarticulate Lingula and Discradisca Stenzel, 1964, and micromorphic rhynchonellide Cryptopora Jeffreys, 1869 were recognized (Bitner \& Cahuzac 2004, 2013; Emig et al. 2007). 


\section{GEOLOGICAL SETTING}

Marine Upper Oligocene deposits crop out only in the south-western part of the Aquitaine Basin (Fig. 1; Cahuzac et al. 1995; Lozouet 2004). They are of transgressive character, having been deposited after a major regression related to the global sea-level fall at the Lower-Upper Oligocene boundary (Vail et al. 1977; Dolin et al. 1985). On the basis of the calcareous nannoplankton these deposits are referred to the zones NP24 and NP25 that correspond with the Chattian (Cahuzac et al. 1995). Moreover, based on neritic larger foraminifera abundant in these levels, they are attributed to the SBZ 23 biozone (Shallow Benthic Zone) of Cahuzac \& Poignant (1997). They contain a rich benthic fauna, composed chiefly of gastropods, bivalves, corals, serpulids, bryozoans, and brachiopods, and are interpreted as having been deposited under tropical/subtropical conditions (Lozouet 2004).

Brachiopods were found at several localities (Fig. 1) in the Chattian deposits represented by various facies (Cahuzac et al. 1995; Lozouet 2004). In the north, in the vicinity of Dax (Bezoye, Estoti, Abesse) shallow-water calcareous facies with coral reefs occur. At Escornebéou the Upper Oligocene is represented by sandy marls and calcareous sands. The localities of Peyrère, Bélus and St-Étienned'Orthe are situated in the area that is considered to be originally a submarine canyon (Kieken 1973). The incision of the paleocanyon which is several hundred meters deep, may be related to the significant drop of sea-level (Dolin et al. 1985; Lozouet 2004). At the head of the paleocanyon (Peyrère, Bélus) the infralittoral to circalittoral facies with dominance of marls occur. To the west the facies become deeper-water and are represented by circalittoral to epibathyal marls and muddy sands at St-Étienne-d'Orthe.

\section{LOCALITIES}

Abesse: Landes, St-Paul-lès-Dax (Abesse);

Bezoye: Landes, St-Paul-lès-Dax (Bezoye);

Escornebéou: Landes, St-Geours-de-Maremne;

Estoti: Landes, St-Paul-lès-Dax (Estoti);

Marcon: Landes, Bélus (Marcon);
Peyrère: Landes, Peyrehorade (Peyrère);

Ruisseau de l'Église: Landes, St-Étienne-d'Orthe.

\section{MATERIAL AND METHODS}

The investigated brachiopods come from seven outcrops, namely Peyrère, Bélus, St-Étienne-d'Orthe, Escornebéou, Bezoye, Estoti and Abesse, in the Aquitaine Basin, SW France (Fig. 1). The material comprises mostly specimens obtained from the bulk samples washed and wet-sieved. The larger fraction was sorted in the field, while finer fractions were picked manually under the binocular microscope at the laboratory. There are also some specimens from the collections of the University of Bordeaux-1. Total number of specimens is 1466 (697 articulated specimens and 769 separate valves).

For isotope analysis, samples were taken by microdrilling from the inner surface of shells. The analyses were done using a Finnigan MAT Delta Plus gas isotope mass spectrometer at the Light Isotope Laboratory of the Institute of Geological Sciences, Polish Academy of Sciences, Warsaw. The carbonate powder was reacted with $100 \%$ orthophosphoric acid under vacuum at $70^{\circ} \mathrm{C}$ in the KIEL IV carbonate device, which was coupled online to a Finnigan MAT Delta Plus gas isotope mass spectrometer. Isotope values are reported as parts per mil in the usual $\delta$-notation relative to the PDB standard (defined via NBS 19). The spectrometer external error amounts to less than \pm 0.08 . We took 20 samples from 20 specimens of two most common species, Megathiris detruncata and Lacazella mediterranea. Additionally two samples were also taken from the third commonest species, Terebratulina retusa. The isotopic paleotemperatures were calculated from the $\delta 18 \mathrm{O}$ values using the equation:

$$
\mathrm{T}\left({ }^{\circ} \mathrm{C}\right)=16.9-4.2\left(\delta_{\mathrm{c}}-\delta_{\mathrm{w}}\right)+0.13\left(\delta_{\mathrm{c}}-\delta_{\mathrm{w}}\right)^{2}
$$

where $\delta_{\mathrm{c}}$ means the $\delta^{18} \mathrm{O}$ values of brachiopod samples relative to the PDB standard and $\delta_{\mathrm{w}}$ means the $\delta 18 \mathrm{O}$ values of seawater relative to the SMOW standard (see Nehyba et al. 2008).

The SEM micrographs were taken in the SEM laboratory of the Institute of Paleobiolo- 


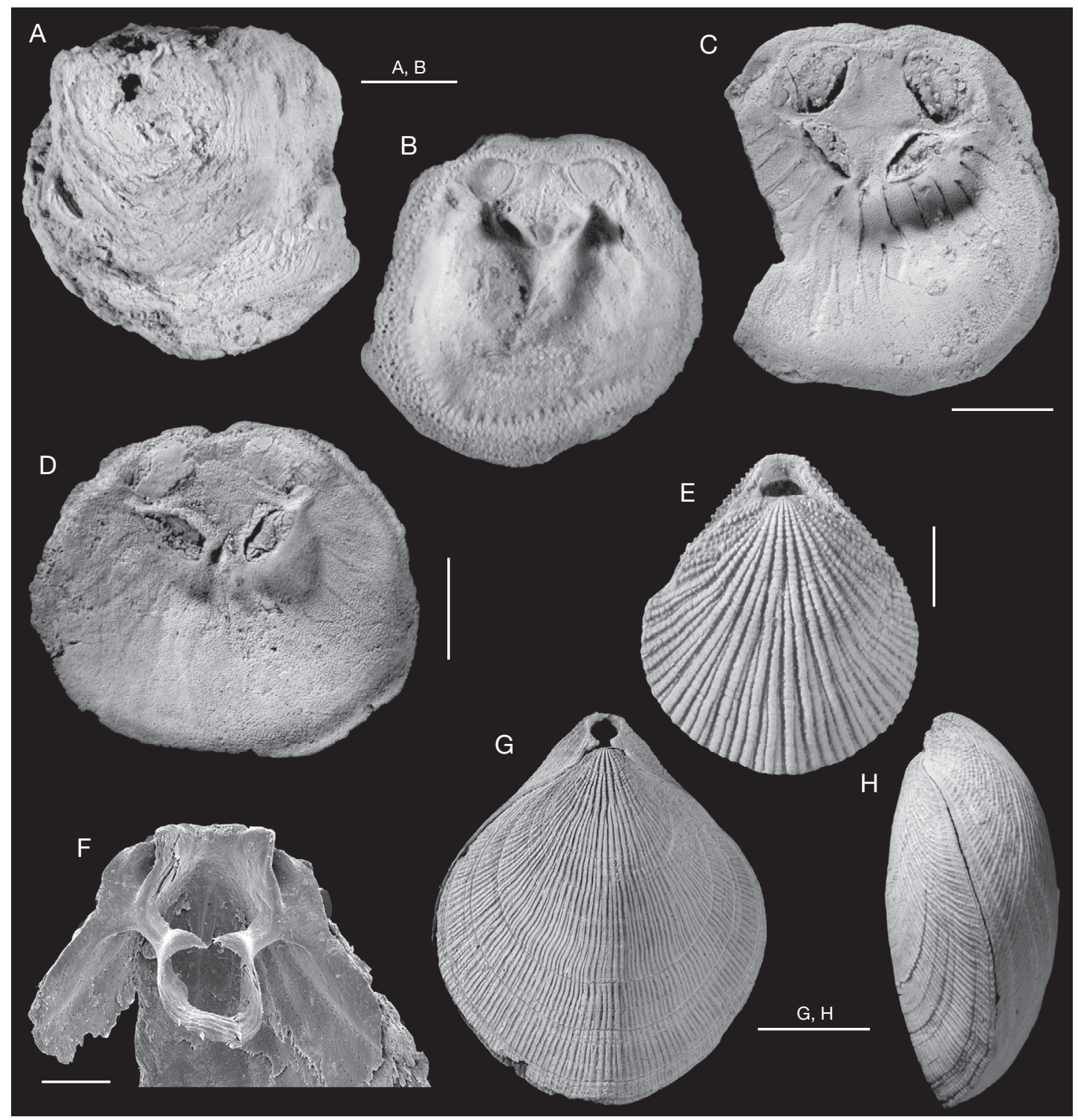

FIG. 2. - A-D, Novocrania anomala (Müller, 1776), Upper Oligocene; A, B, outer and inner views of ventral valve, Peyrère, MNHN. F.A46481; C, D, inner views of dorsal valves, Abesse, MNHN.F.A46483 and MNHN.F.A46484; E-H, Terebratulina retusa (Linnaeus, 1758), Upper Oligocene, Peyrère; $\mathbf{E}$, dorsal view of young complete specimen, MNHN.F.A46485; F, inner view of dorsal valve to show a brachial skeleton, young individual, SEM, MNHN.F.A46486; G, H, dorsal and lateral views of complete specimen, MNHN.F.A46487. Scale bars: A-D, 2 mm; F, $500 \mu \mathrm{m} ; \mathrm{G}, \mathrm{H}, 5 \mathrm{~mm}$.

gy (Warszawa) using a Philips XL-20 scanning microscope.

The investigated material is deposited in the paleontological collection in the Muséum national
d'Histoire naturelle, Paris (MNHN.F, Lozouet coll.), and in the University of Bordeaux-1 (nos 1498 and 1499 of the Peyrot Collection; Nolf-Cahuzac Collection; Larralde Collection; Buisson Collection). 
TABLE 1. - Measurements (in $\mathrm{mm}$ ) of Novocrania anomala (Müller, 1776).

\begin{tabular}{lcc}
\hline Locality & Length & Width \\
\hline Abesse & 14.1 & 15.6 \\
Abesse & 12.0 & 13.8 \\
Abesse & 11.4 & 12.4 \\
Peyrère & 7.1 & 7.2 \\
Peyrère & 5.5 & 5.7 \\
\hline
\end{tabular}

\section{SYSTEMATIC PALEONTOLOGY}

Phylum BRACHIOPODA Duméril, 1805

Subphylum CRANIIFORMEA

Popov, Bassett, Holmer \& Laurie, 1993

Class CRANIATA

Williams, Carlson, Brunton,

Holmer \& Popov, 1996

Order CRANIIDA Waagen, 1885

Superfamily CRANIOIDEA Menke, 1828

Family CraniIDAE Menke, 1828

Genus Novocrania Lee \& Brunton, 2001

TYPE SPECIES. - Patella anomala Müller, 1776, by original designation of Lee \& Brunton (1986: 150).

\section{Novocrania anomala (Müller, 1776)}

(Fig. 2A-D; Table 1)

Patella anomala Müller, 1776: 237.

Crania anomala - Logan 1979: 27-31, text-fig. 4, 5; pl. 1, figs 1-10. — Taddei Ruggiero 1985: 365-366, pl. 1, figs 1-6.

Neocrania anomala - Taddei Ruggiero 1994: 205, 206, pl. 2, fig. 7; 1996: 200, 201, fig. 5. — Logan 1998: 552, fig. 2A-C. — Logan \& Long 2001: 74, fig. 8.3/1-8.

Novocrania anomala - Álvarez \& Emig 2005: 105-107, figs $14,57,58 \mathrm{~A}-\mathrm{I}$.

MATERIALEXAMINED.—Peyrère: oneventral MNHN.FA46481 and two dorsal valves MNHN.F.A46482. — Abesse: nine dorsal valves MNHN.F.A46483, A46484.

OCCURRENCE. - In the fossil record this species is known from the Neogene of the Mediterranean region. Today it lives in the eastern North Atlantic and the Mediterranean Sea, having a wide depth range from 3 to $1665 \mathrm{~m}$ (Logan 1979, 1998; Logan \& Long 2001).

\section{REMARKS}

Novocrania anomala is rare (12 specimens) in the studied material, found only in two localities. The material is poorly preserved, both outer and inner surfaces are usually worn but it corresponds well with that hitherto described (Logan 1979, 1998; Logan \& Long 2001; Álvarez \& Emig 2005). The shell is small with maximum length $15.6 \mathrm{~mm}$, subcircular in outline, wider than long. The posterior adductor muscle scars are large, subcircular, situated near posterior margin in both valves. The anterior adductor muscle scars are oval, elevated. On some specimens mantle canals can be observed (Fig. 2C, D). This is the only inarticulate brachiopod in the investigated assemblage.

\section{Subphylum RHYNCHONELLIFORMEA Williams, Carlson, Brunton, Holmer \& Popov, 1996 \\ Class RHYNCHONELLATA \\ Williams, Carlson, Brunton, Holmer \& Popov, 1996 \\ Order TEREBRATULIDA Waagen, 1883}

Suborder TEREBRATULIDINA Waagen, 1883

Superfamily CANCELLOTHYRIDOIDEA

Thomson, 1926

Family CANCELLOTHYRIDIDAE

Thomson, 1926

Subfamily CANCELLOTHYRIDINAE

Thomson, 1926

\section{Genus Terebratulina d'Orbigny, 1847}

Type SPECIES. - Anomia retusa Linnaeus, 1758, by subsequent designation of Brunton et al. (1967: 176).

\section{Terebratulina retusa (Linnaeus, 1758)}

(Fig. 2E-H; Table 2)

Anomia retusa Linnaeus, 1758: 701, no. 191. 


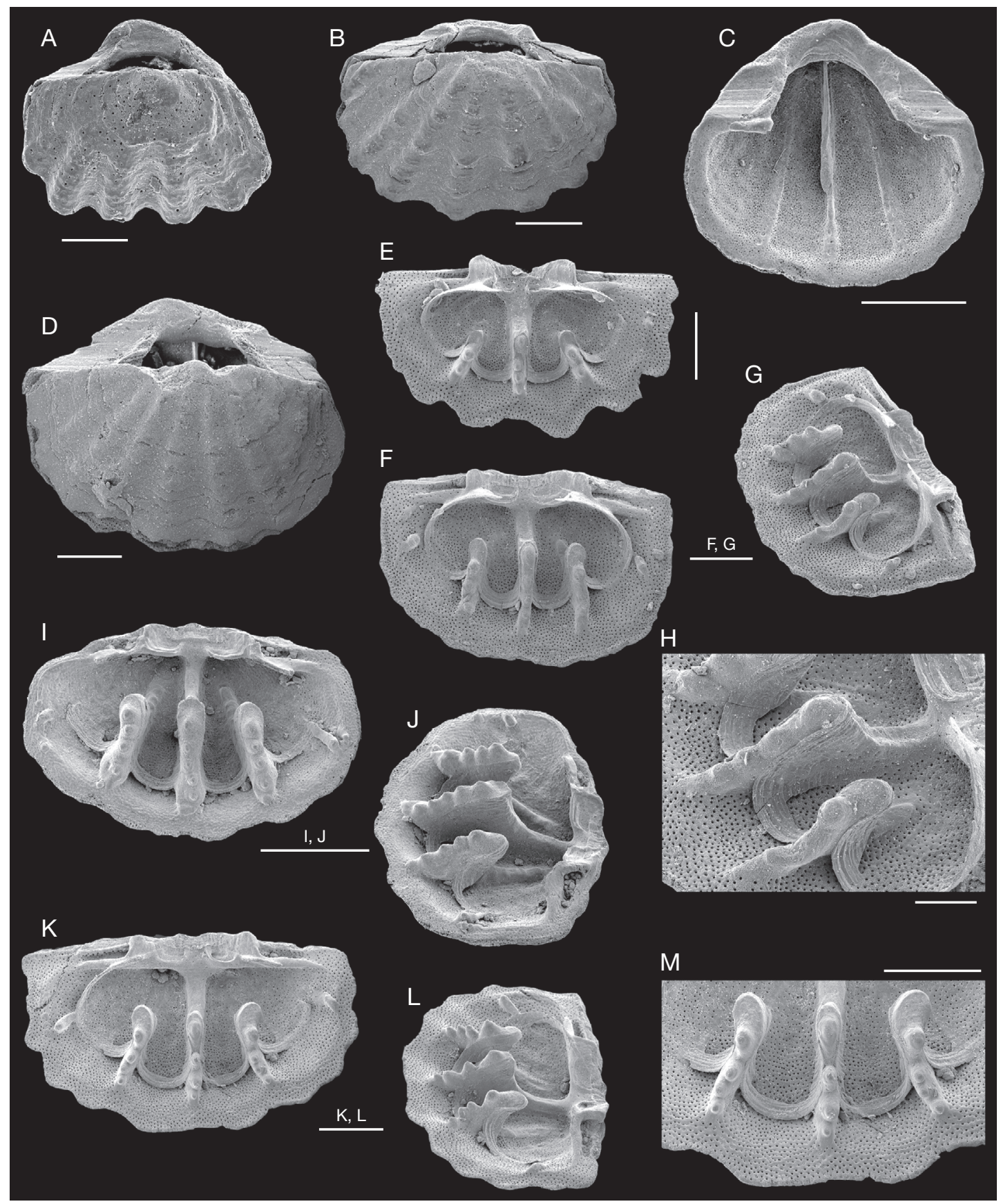

FIG. 3. - Megathiris detruncata (Gmelin, 1791), Upper Oligocene, Abesse: A, B, D, dorsal views of complete specimens, MNHN.F.A46491-A46493; C, inner view of ventral valve, MNHN.F.A46494; $\mathbf{E}$, inner view of dorsal valve of young individual, MNHN.F.A46495; F-M, inner and oblique views of dorsal valves, and enlargements (H, M) to show details of septa and loop, MNHN.F.A46496-A46498. All SEM. Scale bars: A, H, 500 m; B, D-G, K-M, 1 mm; C, I, J, 2 mm. 
TABLE 2. - Measurements (in $\mathrm{mm}$ ) of Terebratulina retusa (Linnaeus, 1758).

\begin{tabular}{lccc}
\hline Locality & Length & Width & Thickness \\
\hline Peyrère & 14.8 & 12.1 & - \\
Peyrère & 10.0 & 6.4 & - \\
Peyrère & 18.1 & 15.7 & 7.7 \\
\hline
\end{tabular}

TABle 3. - Measurements (in $\mathrm{mm}$ ) of Megathiris detruncata (Gmelin, 1791).

\begin{tabular}{lccc}
\hline Locality & Length & Width & Thickness \\
\hline Peyrère & 6.5 & 7.3 & 3.4 \\
Peyrère & 5.6 & 6.2 & 3.0 \\
Peyrère & 4.9 & 6.5 & 2.9 \\
Bélus & 5.9 & 6.7 & 3.2 \\
Abesse & 3.2 & 4.6 & 2.1 \\
\hline
\end{tabular}

Terebratulina retusa - Logan 1979: 37-43, text-fig. 8, pl. 3, figs 1-18. — Gaetani \& Saccà 1985: 15-16, pl. 7, figs 5-10; pl. 9, figs 6-9. — Taddei Ruggiero 1985: 367-369, pl. 2, figs 1-7, pl. 3, figs 1-8, pl. 4, figs 1-7; 1994: 208, pl. 2, figs 1-3. — Bitner \& Moissette 2003: 472, fig. 6A-F. — Bitner \& Dulai 2004: pl. 3, fig. 1. Álvarez \& Emig 2005: 139, 140, figs 24D-F, 27D, 27F, 28, 53B, 54E-F, 61.

MATERIAl EXAMINED. — Peyrère: 74 complete specimens, 11 ventral and 15 dorsal valves, and many fragments MNHN.F.A46485-A46488 and A46555. — Bélus: five complete specimens, two ventral and one dorsal valves MNHN.F.A46489. — St-Étienne-d'Orthe: one ventral valve MNHN.F.A46490.

OCCURRENCE. - This species is well known in the Neogene deposits of the Mediterranean province but rare in the Central Paratethys (Dreger 1889; Bitner \& Dulai 2004), and it is present in the Aquitaine Middle Miocene (Bitner \& Cahuzac 2004). Today it occurs in the north-eastern North Atlantic and the Mediterranean Sea (Logan 1979; Brunton \& Curry 1979; Curry 1982). Its depth range is from 18 to $2157 \mathrm{~m}$ (Logan 2007).

\section{REMARKS}

This species has been found in three localities but only in one, Peyrère, it is numerous. The investigated specimens, although often crushed and/ or damaged, are consistent with those hitherto described having, however, smaller size (Logan 1979; Taddei Ruggiero 1985; Gaetani \& Saccà
1985; Álvarez \& Emig 2005). The shell is ovate to subpentagonal, biconvex, covered with numerous, fine ribs that are coarser and strongly beaded in young individuals (Fig. 2E). The cardinalia are typical for the genus with prominent inner socket ridges and deep dental sockets. The loop is preserved only in a young specimen, with crural processes not yet united (Fig. 2F).

\section{Suborder TEREBRATELLIDINA} Muir-Wood, 1955

Superfamily MEgaTHYRIDOIDEA Dall, 1870

Family MEGATHYRIDIDAE Dall, 1870

$$
\text { Genus Megathiris d'Orbigny, } 1847
$$

TYPe SPECIES. - Anomia detruncata Gmelin, 1791, by subsequent designation of Dall (1920: 331).

\section{REMARKS}

Dall (1920) showed that the first binominal valid name given to this species was Anomia detruncata Gmelin, 1791, and this should therefore be used for the type species (see also Thomson 1927: 213).

\section{Megathiris detruncata (Gmelin, 1791)}

(Fig. 3A-M; Table 3)

Anomia detruncata Gmelin, 1791: 3347.

Megathyris decollata - Peyrot 1932: 485, 486, pl. 17, figs 11-13.

Megathiris detruncata - Logan 1979: 55-59, text-figs 15, 16; pl. 6, figs 1-13. - Gaetani \& Saccà 1985: 17, 18, pl. 9, figs 10-12; pl. 10, figs 11-14. — Taddei Ruggiero 1985: 369-371, pl. 5, figs 1-9; pl. 6, figs 1-6; pl. 7, figs 1-9, 14; 1994: 208, pl. 3, figs 6-9; 1996: 202. Bitner 1990: 135-138, text-figs 3, 4; pl. 3, figs 1-8; pl. 6, figs 1-7. - Bitner \& Moissette 2003: 473, 474, fig. 6G, H. - Kroh 2003: 147, 148, pl. 1, figs 4-6. Bitner \& Dulai 2004: 74, 76, pl. 3, figs 11-15; 2008: 35, 36, fig. 5.1-4. - Álvarez \& Emig 2005: 147, 148, figs 25C, 63-66. - Dulai 2007: 2, 3, fig. 2.1-2; 2010a: 26, pl. 3, fig. 1a, b. - Bitner \& Schneider 2009: 127, fig. 6A-C.

Material EXAMINED. — Peyrère: 120 complete specimens, 32 ventral and 42 dorsal valves, MNHN.F.A46502 and 


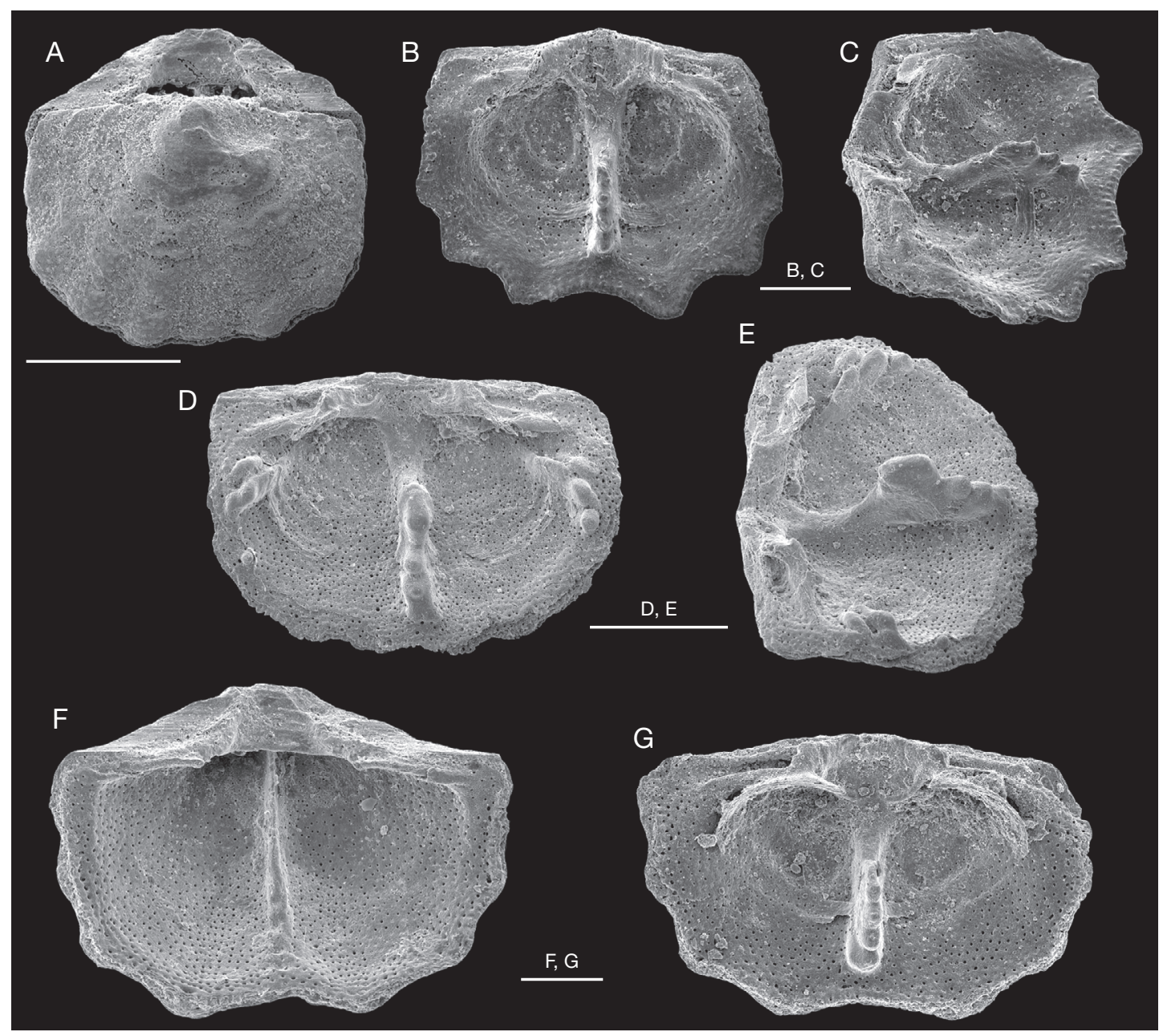

FIG. 4. - Argyrotheca cuneata (Risso, 1826), Peyrère, Upper Oligocene; A, dorsal view of complete specimen, MNHN.F.A46507; B-E, inner and oblique lateral views of dorsal valves MNHN.F.A46508-A46509; F, G, ventral and dorsal interiors of one specimen, MNHN.F.A46510-A46511. All SEM. Scale bars: A, D, E, 1 mm; B, C, F, G, 500 mm.

A46554. - Abesse: 12 complete specimens, 72 ventral and 101 dorsal valves MNHN.F.A46491-A46501. — Estoti: five ventral valves, MNHN.F.A46503. - Bezoye: four complete specimens, three ventral and 17 dorsal valves, MNHN.F.A46504. - Bélus: ten complete specimens, three ventral and five dorsal valves, MNHN.F.A46505 and A46506.

OCCURRENCE. - This species is known in the fossil record since the Eocene and lives today in the Mediterranean and the north-eastern North Atlantic at the depth from 5 to $896 \mathrm{~m}$ (Logan 2007). Its occurrence in the Caribbean Sea reported by Cooper (1977) is questionable (see also Logan 2007).

\section{REMARKS}

Megathiris detruncata is one of the most common species (more than 400 specimens) in the investigated assemblage, found in five localities. It was already recorded from the studied area (Peyrot 1932; Lozouet 2004). The specimens from the Aquitaine Basin correspond well to those hitherto described (e.g., Logan 1979; Taddei Ruggiero 1985; Bitner 1990; Bitner \& Schneider 2009). The shell is small (our largest specimen is a dorsal valve 7.0 long and $8.1 \mathrm{~mm}$ wide), transversely ovate in outline, covered with few wide, rounded ribs. The 
TABLE 4. - Measurements (in mm) of Argyrotheca cuneata (Risso, 1826).

\begin{tabular}{lccc}
\hline Locality & Length & Width & Thickness \\
\hline Peyrère & 3.0 & 3.2 & - \\
Peyrère & 2.3 & 3.0 & 1.3 \\
Peyrère & 2.2 & 2.3 & 1.2 \\
\hline
\end{tabular}

foramen is large, triangular, bordered by two narrow deltidial plates. Internally, this species is characterized by the presence of three septa on a dorsal valve what makes it an easily recognizable species.

\section{Genus Argyrotheca Dall, 1900}

Type SPECIES. - Terebratula cuneata Risso, 1826, by original designation of Dall (1900: 44).

\section{Argyrotheca cuneata (Risso, 1826) (Fig. 4A-G; Table 4)}

Terebratula cuneata Risso, 1826: 388, pl. 12, fig. 179.

Argyrotheca cuneata - Logan 1979: 45-49, text-figs 11, 12; pl. 4, figs 1-12. - Bitner 1990: 138-140, textfig. 5-6, pl. 4, figs 1-9; 1993: 149-150, pl. 2, figs 1-6; pl. 3, figs 1-6. - Taddei Ruggiero 1996: 202. - Bitner \& Pisera 2000: 9, pl. 1, figs 1-7. - Kroh 2003: 148, pl. 1, figs 1-3. - Bitner \& Dulai 2004: pl. 3, figs 2-6. - Bitner \& Kaim 2004: 196, fig. 2A-C. - Álvarez \& Emig 2005: 149-153, figs 25A-B, 27A, C, E, 44, 45, 67-69. - Dulai 2007: 4, fig. 3.1-7.

MATERIAL EXAMINED. - Peyrère: six complete specimens, six ventral and three dorsal valves, MNHN.F.A46507A46512.

OCCURRENCE. - This species is very common in the Miocene of the Central Paratethys and Neogene of the Mediterranean region. Today it lives in the Mediterranean Sea and North Atlantic (Brunton \& Curry 1979; Logan 1979, 1983, 1988), having depth range of 5 to $645 \mathrm{~m}$ (Logan 2007). Argyrotheca cf. cuneata was also recorded from off Brazil (Simôes et al. 2004).

\section{REMARKS}

Argyrotheca cuneata is rare in the studied assemblage and was found in only one locality. The shell is small, rectangular with greatest width usually at hinge line. The shell surface is covered with 6-8 single, low and rounded ribs. The foramen is large, triangular with a wide pedicle collar supported by a septum. The teeth are widely separated lying parallel to the hinge line. The dorsal median septum is high, triangular in profile with 3-4 serrations.

Argyrotheca cuneata can be distinguished from a second Argyrotheca species, A. bitnerae Dulai, 2011 and Joania cordata (Risso, 1826) in rectangular outline and ribbed surface. Additionally, A. cuneata differs from $J$. cordata in lacking tubercles on the inner margin. The absence of margin tubercles distinguishes it also from Joania peyrerensis n. sp.

In shell outline and ornamentation $A$. cuneata resembles Megathiris detruncata, being, however, easily distinguishable internally from the latter species; $M$. detruncata has three septa on the dorsal valve.

\section{Argyrotheca bitnerae}

Dulai in Dulai \& Stachacz, 2011

(Fig. 5A-M; Table 5)

Argyrotheca bitnerae Dulai in Dulai \& Stachacz, 2011: 285-291, figs 3, 4 .

Argyrotheca cistellula - Barczyk \& Popiel-Barczyk 1977: 161, 162, pl. 1, figs 1-3. - Popiel-Barczyk \& Barczyk 1990: 172, 173, pl. 2, figs 11, 13.

Argyrotheca sp. - Barczyk \& Popiel-Barczyk 1977: 164, pl. 1, figs 6, 7 .

Material examined. - Peyrère: 13 complete specimens, 2 ventral and 7 dorsal valves, MNHN.F.A46513, A46514. - Abesse: eight complete specimens and six dorsal valves, MNHN.F.A46515-A46517. — Estoti: three complete specimens, two ventral and six dorsal valves, MNHN.F.A46518-A46520. — Bélus: five complete specimens, three ventral and one dorsal valves, MNHN.F.A46521, A46522.

OCCURRENCE. - This species has been so far recorded from the Middle Miocene of the northern part of the Central Paratethys (Dulai \& Stachacz 2011).

\section{DESCRIPTION}

Shell small (maximum length $3.3 \mathrm{~mm}$ ), thin, subtriangular in outline, weakly dorsibiconvex. Dorsal valve nearly semicircular in outline. Shell surface 


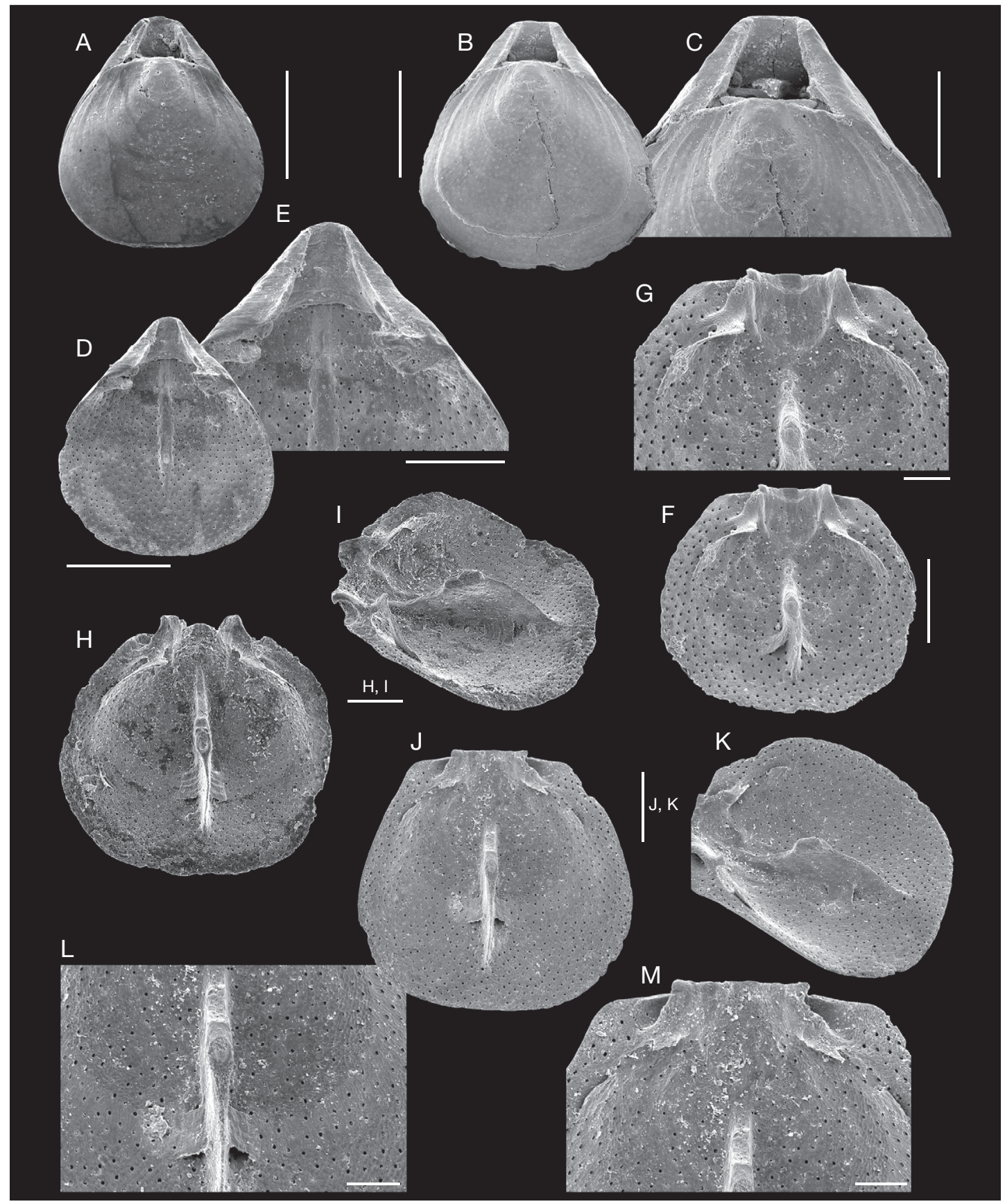

FIG. 5. - Argyrotheca bitnerae Dulai, 2011, Upper Oligocene: A, dorsal view of complete specimen, Peyrère, MNHN.F.A46513; B, C, dorsal view of complete specimen and enlargement of the umbonal part to show details of the beak, Abesse, MNHN.F.A46515; D, E, inner view of ventral valve and enlargement of umbonal part to show details of pedicle collar and teeth, Estoti, MNHN.F.A46518; F, G, inner view of dorsal valve and enlargement of cardinalia (G), Bélus, MNHN.F.A46521; H, I, inner and oblique lateral views of dorsal valve, visible high median septum without serrations, Estoti, MNHN.F.A46519; J-M, inner and oblique lateral views of dorsal valve, and enlargement of descending branches but-

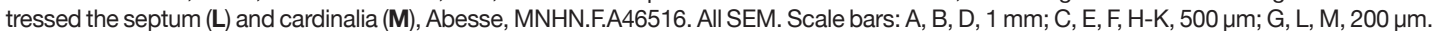


TABlE 5. - Measurements (in mm) of Argyrotheca bitnerae Dulai, 2011.

\begin{tabular}{lccc}
\hline Locality & Length & Width & Thickness \\
\hline Abesse & 2.6 & 2.0 & 0.8 \\
Abesse & 3.3 & 2.6 & 1.3 \\
Abesse & 2.1 & 1.7 & 0.7 \\
Estoti & 3.3 & 2.9 & 1.4 \\
Bélus & 2.5 & 2.1 & 1.0 \\
Bélus & 1.4 & 1.3 & 0.5 \\
\hline
\end{tabular}

smooth, coarsely punctate with numerous growth lines. Anterior commissure rectimarginate. Hinge line short. Beak high, straight; beak ridges sharp. Interarea very narrow. Foramen large, triangular, hypothyrid, bordered by two deltidial plates forming narrow ridges.

Ventral valve interior with small, hooked teeth projecting into delthyrium. Pedicle collar broad, sessile attached valve floor anteriorly. Median septum low, extending from pedicle collar to about mid-valve.

Dorsal valve interior with well developed, narrow inner socket ridges. Dental sockets deep. Cardinal process as small depression. Crura very short, as are crural processes (see Fig. 5F-I). Descending branches fuse with valve floor (Fig. 5F, H), and emerge to attach to median septum. Median septum high, triangular in profile, without serrations (Fig. 5I, K).

\section{REMARKS}

This species is relatively common in the studied material being found in four localities. The investigated specimens correspond well, both externally and internally, to those described as Argyrotheca bitnerae by Dulai in Dulai \& Stachacz (2011) from the Middle Miocene of Poland. The Oligocene specimens differ from the Miocene ones in being slightly larger and having the septum without serrations. Dulai in Dulai \& Stachacz (2011) observed 2-3 weak serrations at the anterior slope of the septum.

This brachiopod was earlier attributed to the species $A$. cistellula (Searles-Wood, 1841) by Barczyk \& Popiel-Barczyk (1977) and Popiel-Barczyk \& Barczyk (1990). However, A. cistellula has a shell transversely subrectangular in outline, with a wide straight hinge line (Logan 1979). In addition, the pedicle collar in A. cistellula is excavated anteriorly,
TABLE 6. - Measurements (in mm) of Joania cordata (Risso, 1826).

\begin{tabular}{lccc}
\hline Locality & Length & Width & Thickness \\
\hline Abesse & 3.3 & 3.0 & 1.2 \\
Abesse & 3.3 & 2.7 & - \\
Abesse & 3.0 & 2.5 & 1.1 \\
Bélus & 2.5 & 2.3 & - \\
Bélus & 2.3 & 2.0 & 0.9 \\
\hline
\end{tabular}

while in $A$. bitnerae the pedicle collar is close to the valve floor.

In shell shape, smooth surface, sessile pedicle collar and short crura with blunt crural processes $A$. bitnerae bears a close resemblance to the Early Miocene species $A$. kupei Hiller, Robinson \& Lee, 2008 from New Zealand, differing, however, in having smooth slope of the dorsal septum (Hiller et al. 2008; Hiller 2011). In A. kupei the anterior slope of septum has 2-3 knob-like extensions.

Externally, in smooth surface and triangular outline with a short hinge margin, the studied specimens resemble Joania cordata but they differ strongly from the latter species internally. Joania cordata possesses a prominent cardinal process and marginal tubercles on inner surface of both valves (Logan 1979; Álvarez et al. 2008).

\section{Genus Joania Álvarez, Brunton \& Long, 2008}

TYPe SPECIES. - Terebratula cordata Risso, 1826, by original designation of Álvarez et al. (2008: 401).

\section{Joania cordata (Risso, 1826)}

(Fig. 6A-I; Table 6)

\section{Terebratula cordata Risso, 1826: 389.}

Argyrotheca cordata - Logan 1979: 50-54, text-figs 13, 14, pl. 5, figs 1-12. — Taddei Ruggiero 1985: 371,372, pl. 7, figs 10-14; 1994: 208, pl. 2, fig. 1-3; 1996: 202. — Bitner 1990: 140-143, text-figs 7, 8, pl. 5, figs 1-14, pl. 7, fig. 1; 1993: 150, pl. 4, figs 1-5; pl. 5, figs 1-8. - Bitner \& Pisera 2000: 9-10, pl. 2, figs 1-9. - Bitner \& Dulai 2004: pl. 3, figs 9, 10. — Bitner \& Kaim 2004: 196, 197, figs 2D-K, 3A-E. — Álvarez \& Emig 2005: 155158, figs 25F, G, 47, 48. — Dulai 2007: 4-5, fig. 4.1-9. 


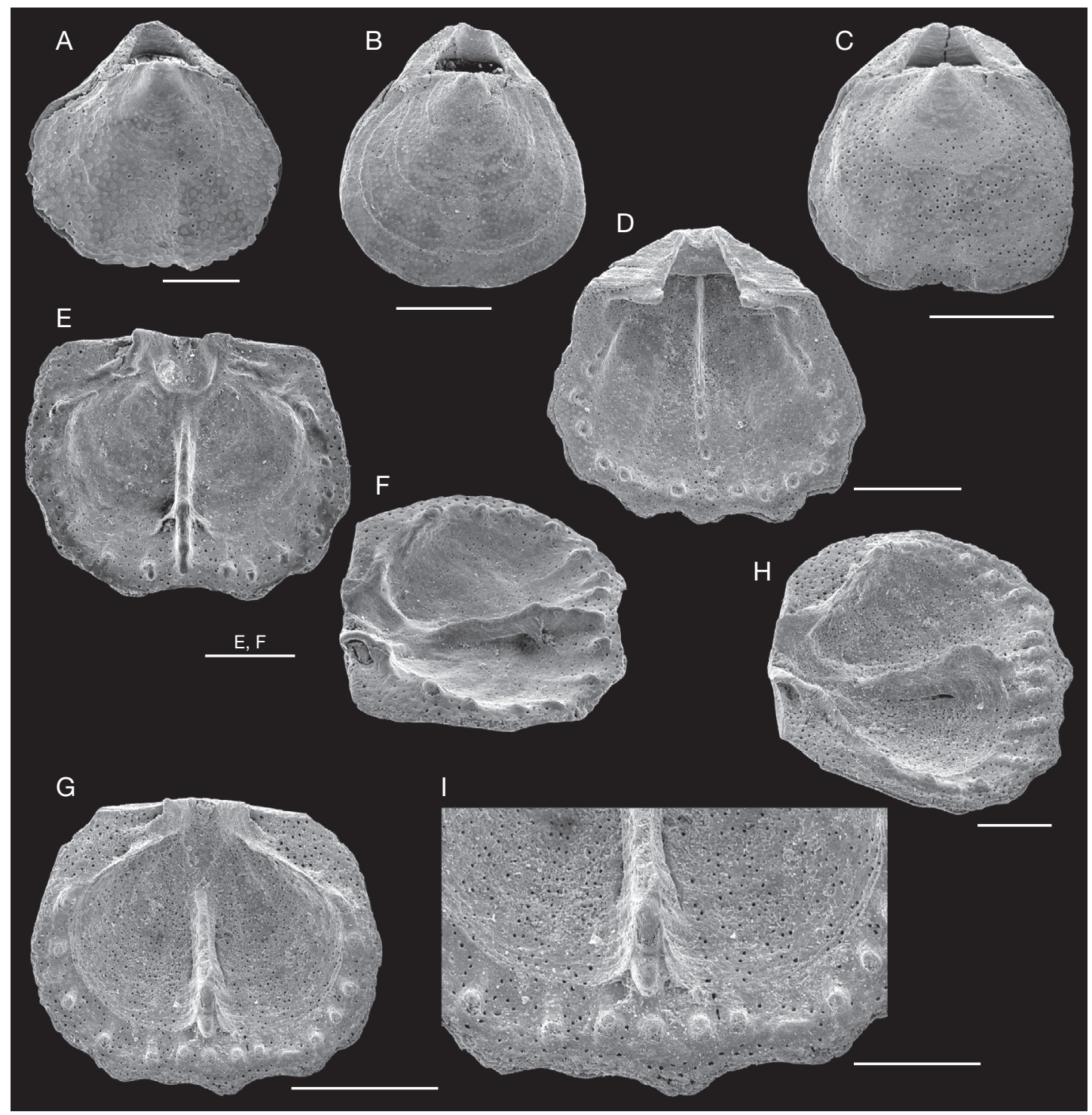

FIG. 6. - Joania cordata (Risso, 1826), Upper Oligocene: A-C, dorsal views of complete specimens; A, Estoti, MNHN.F.A46523, B, C, Abesse, MNHN.F.A46526-A46527; D, inner view of ventral valve, Bélus, MNHN.F.A46529; E, F, inner and oblique lateral views of dorsal valve, young individual, Estoti, MNHN.F.A46524; G-I, inner, oblique lateral views of dorsal valve, and enlargement of anterior part to show septum and connection with a loop, Bélus, MNHN.F.A46530. All SEM. Scale bars: A, E, F, H, I, 500 m; B-D, G, 1 mm.

Joania cordata - Álvarez, Brunton \& Long 2008: 400402, fig. 4C-D, 5A-F, 11-13.

Material EXAMINED. - Peyrère: three complete specimens, three ventral and one dorsal valves. Abesse: seven complete specimens, four ventral and two dorsal valves, MNHN.F.A46526-A46528 and A46551. Estoti: one complete specimen MNHN.F.A46523 and five dorsal valves MNHN.F.A46524-A46525. Bélus: four complete specimens, three ventral and four dorsal valves, MNHN.F.A46529-A46531.

OCCURRENCE. - This species is common in the Neogene of the Central Paratethys and the Mediterranean 
TABLE 7. - Measurements (in $\mathrm{mm}$ ) of Joania peyrerensis $\mathrm{n} . \mathrm{sp}$.

\begin{tabular}{lccc}
\hline Locality & Length & Width & Thickness \\
\hline Bélus & 2.3 & 2.3 & 1.0 \\
Bélus & 2.9 & 3.0 & 1.3 \\
Peyrère (holotype) & 2.5 & 2.7 & 1.3 \\
\hline
\end{tabular}

province, living today in the north-eastern North Atlantic and the Mediterranean Sea (Logan 1979, 1983, 1988) at the depth of 3 to $600 \mathrm{~m}$ (Logan 2007).

\section{REMARKS}

The genus Joania was recently established by Álvarez et al. (2008) for those Argyrotheca species that have a narrow hinge line, prominent cardinal process and tubercles on the inner margin.

The specimens from the Aquitaine Basin agree well with those described from the Miocene of the Central Paratethys (Bitner 1990, 1993; Bitner \& Pisera 2000; Bitner \& Kaim 2004), differing from the Recent ones described and illustrated by Logan (1979) in having a lower median septum. The shell is small, smooth or covered with poorly defined, shallow ribs. The large foramen is triangular with a wide pedicle collar supported by a low median septum. The inner socket ridges are narrow but high, and the cardinal process is prominent. The specimens bear tubercles on the inner margin of both valves.

\section{Joania peyrerensis $\mathrm{n}$. $\mathrm{sp}$.} (Fig. 7A-I; Table 7)

TYPE MATERIAL. - Holotype MNHN.F.A46532: specimen figured in Fig. 7A-C; paratypes MNHN.F.A46533, A46534: specimens figured in Fig. 7D-I.

ETYMology. - Referring to the name of type locality, Peyrère.

Material eXAmined. - Peyrère: one complete specimen. — Bélus: three complete specimens and one dorsal valve.

Type horizon and LOCALITY. - Upper Oligocene, Peyrère, Aquitaine Basin, SW France.

Diagnosis. - Small, rounded subrectangular Joania with surface ornamented by six to eight distinct ribs; teeth triangular; dorsal septum high, triangular in profile with serrations; tubercles on inner margin of both valves.

\section{DESCRIPTION}

Shell small, not exceeding $3 \mathrm{~mm}$ in length, rounded subrectangular in outline with maximum width at mid-valve, weakly biconvex. Shell surface covered with 6 to 8 distinct ribs. Hinge line shorter than maximum width, slightly curved. Anterior commissure rectimarginate. Beak high with distinct beak ridges. Interarea narrow. Foramen large, triangular, hypothyrid flanked by elevated, narrow deltidial plates.

Ventral valve interior with plate-like, triangular teeth (Fig. 7F-H). Pedicle collar wide, excavate anteriorly, supported by a slender septum that extends beyond mid-valve. On inner surface radial ridges terminating in tubercles (Fig. 7I).

Dorsal valve interior with narrow but high inner socket ridges. Dental sockets deep. Cardinal process distinct. Septum high, triangular in profile, with 4 serrations. Numerous tubercles on inner margin (Fig. 7D, E). Loop not preserved.

\section{REMARKS}

Álvarez et al. (2008) created Joania as a monospecific genus, however, since that time several Argyrotheca species have been transferred into the genus Joania, based mostly on the important diagnostic character - numerous radial ridges terminating anteriorly in tubercles on the inner margin. The presence of marginal tubercles in the specimens from the Aquitaine Basin supports their attribution to the genus Joania.

In the ornamentation of 6-8 distinct, sharp ribs J. peyrerensis $\mathrm{n}$. sp. can be easily distinguished from other so far described Joania species. The shell surface of J. cordata is smooth or covered with almost imperceptible costae (Logan 1979; Bitner 1990; Álvarez et al. 2008). In addition, both species differ in the nature of the teeth; in J. peyrerensis n. sp. the teeth form a triangular plate, while in J. cordata they are hooked.

The shell of a Recent Indo-Pacific species J. arguta (Grant, 1983) is also completely smooth without any costae (Bitner 2008; Simon 2010). The teeth in this species are, similarly like in J. cordata, hooked given off dorsally, thus differing clearly from $J$. peyrerensis $\mathrm{n}$. $\mathrm{sp}$.

The studied specimens differ strongly from the Lower Pleistocene species from southern Italy, 


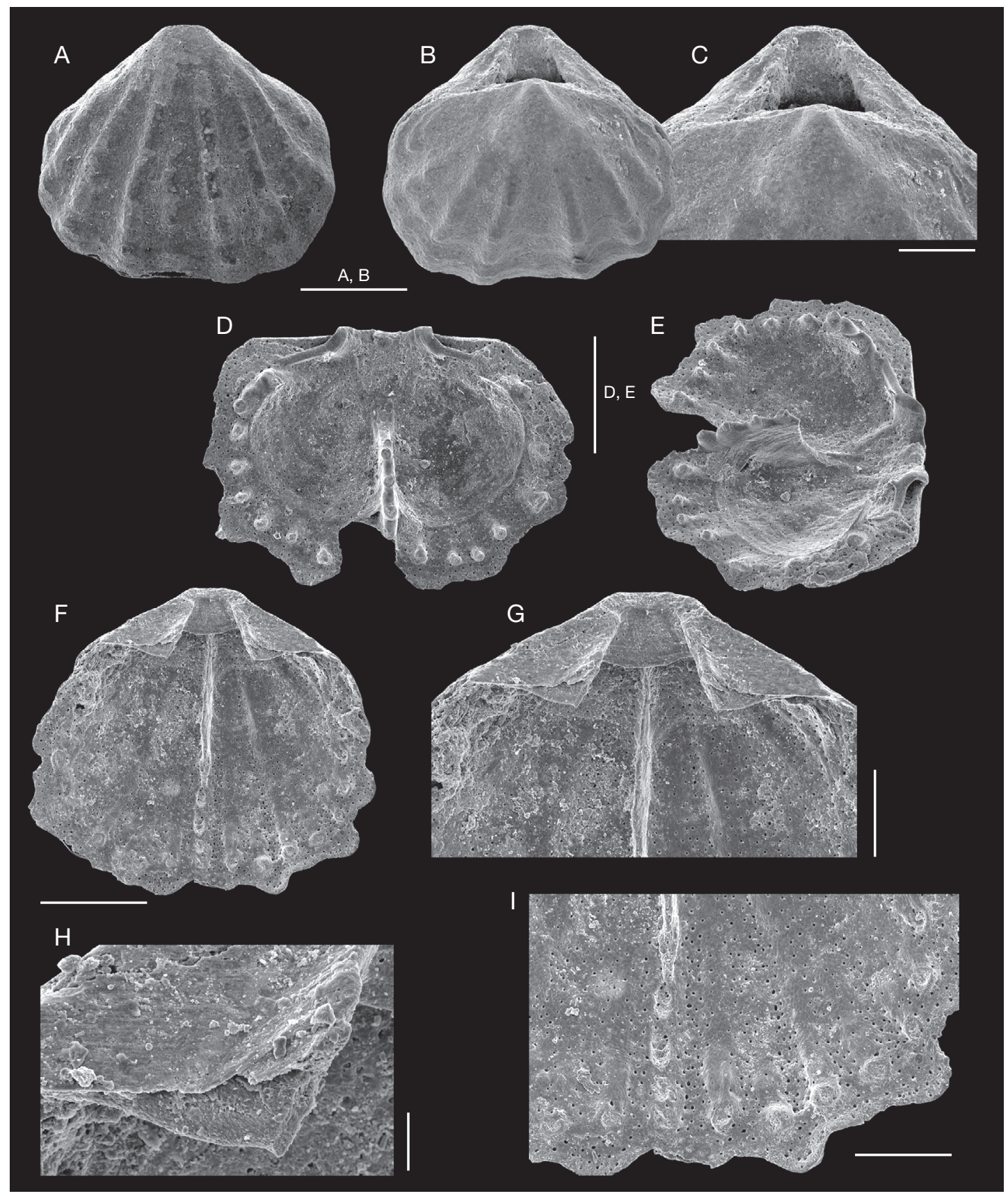

FIG. 7. - Joania peyrerensis n. sp., Upper Oligocene: A-C, ventral and dorsal views of complete specimen, and enlargement of posterior part to show details of the beak, holotype MNHN.F.A46532, Peyrère; $\mathbf{D}$, E, inner and oblique lateral views of dorsal valve, paratype MNHN.F.A46533, Bélus; F-I, inner view of ventral valve, enlargement of posterior part (G) and details of left tooth $(\mathbf{H})$ and enlargement of anterior part (I) to show radial ridges terminating anteriorly in tubercules, paratype MNHN.F.A46534, Bélus. All SEM. Scale bars: A, B, D-F, $1 \mathrm{~mm}$; C, G, I, $500 \mu \mathrm{m} ; \mathrm{H}, 100 \mu \mathrm{m}$. 


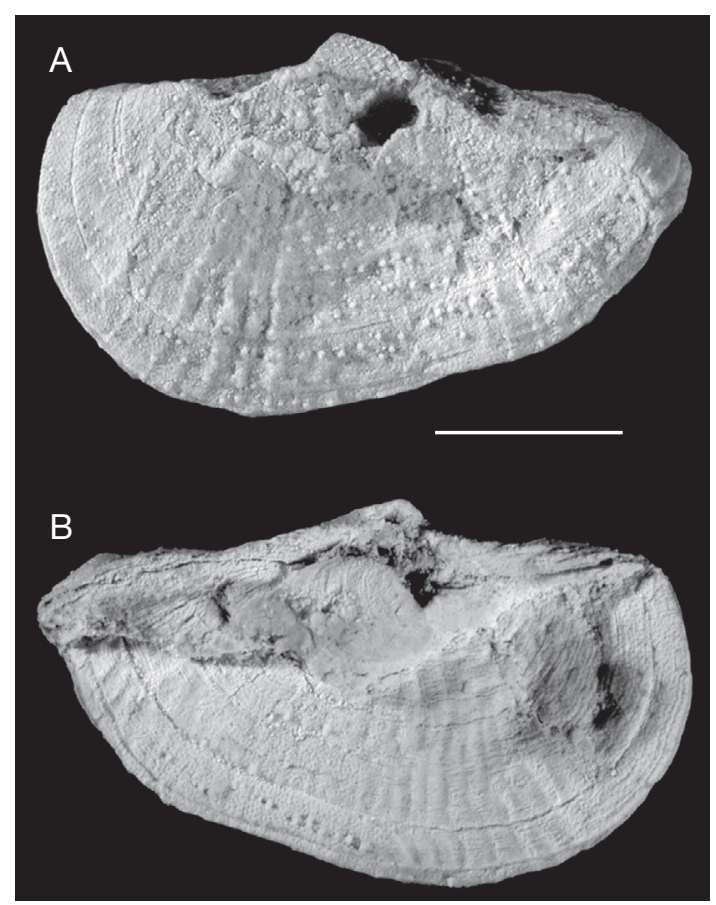

FIG. 8. - Megerlia truncata (Linnaeus, 1767), Upper Oligocene, Peyrère (MNHN.F.A46535), complete specimen in ventral (A) and dorsal (B) views. Scale bar: $3 \mathrm{~mm}$.

Joania ageriana, originally described as Argyrotheca ageriana by Taddei Ruggiero (1993). Joania ageriana is much larger, reaching $7 \mathrm{~mm}$ in length, and ornamented by 14 to 18 rounded ribs (Taddei Ruggiero 1993, 1994)

Dulai (2010a) attributed a single dorsal valve from the Late Miocene of Italy to Joania aff. falunica (de Morgan, 1915), recognizing in this brachiopod diagnostic characters of the genus. The poor material prevents any formal description of a new species.

Superfamily KRAUSSINOIDEA Dall, 1870 Family KraUsSinidae Dall, 1870

Genus Megerlia King, 1850

TYPE SPECIES. - Anomia truncata Linnaeus, 1767, by the original designation of King (1850: 145).
TABLE 8. - Measurements (in $\mathrm{mm}$ ) of Megerlia truncata (Linnaeus, 1767).

\begin{tabular}{lcc}
\hline Locality & Length & Width \\
\hline Peyrère & $? 6.3$ & 10.1 \\
Peyrère & 10.3 & - \\
Peyrère & 6.7 & 9.3 \\
\hline
\end{tabular}

\section{Megerlia truncata (Linnaeus, 1767)}

(Fig. 8A, B; Table 8)

Anomia truncata Linnaeus, 1767: 1152, no. 229.

Megerlia truncata - Logan 1979: 68-72, text-fig. 21; pl. 9, figs 1-23. - Taddei Ruggiero 1985: 372-374, pl. 8, figs 1-6, pl. 9, figs 1-5, pl. 10, figs 1-11, pl. 11, figs 1-10; 1994: 210, pl. 3, figs 3, 4. - Bitner 1990: 145-147, text-fig. 10, pl. 2, figs 6-9, pl. 7, figs 3-6, pl. 8, figs 1-7. - Álvarez \& Emig 2005: 167, 168, figs 25J-M, 53F, 71. - Dulai 2010a: 28, pl. 3, figs 4, 5.

Megerlia montruosa - Taddei Ruggiero 1985: 374, 375, pl. 1, figs 7-11; 1994: 210, pl. 3, fig. 5.

MATERIAL EXAMINED. - Peyrère: four complete specimens, one ventral and two dorsal valves, MNHN.F.A46535, A46536. Material is strongly crushed.

OCCURRENCE. - This is one of the commonest species in the Miocene of the Central Paratethys and the Mediterranean region, being also very common today in the Mediterranean and the western Atlantic with the wide depth range from 8 to $1086 \mathrm{~m}$ (Logan 2007). Megerlia truncata is also recorded from the Indian Ocean (Cooper 1981; Bitner et al. 2008).

\section{REMARKS}

Megerlia truncata is very rare in the investigated assemblage, found only in one locality. The material is poorly preserved, all specimens are crushed, preventing examination of internal structure. However, the size and characteristic ribbed ornamentation support attribution to this species. This is the first record of this species from the Oligocene but the genus Megerlia was already reported from the Oligocene of Hungary (Dulai 2010b).

Order THECIDEIDA Elliott, 1958 Superfamily THECIDEOIDEA Gray, 1840 
Family THECIDEIDAE Gray, 1840

Subfamily LACAZELLINAE Backhaus, 1959

Genus Lacazella Munier-Chalmas, 1880

TYPE SPECIES. - Thecidea mediterranea Risso, 1826, by original designation of Munier-Chalmas (1880: 279).

Lacazella mediterranea (Risso, 1826)

(Fig. 9A-L; Table 9)

Thecidea mediterranea Risso, 1826: 394, pl. 12, fig. 183.

Thecidea (Lacazella) mediterranea - Peyrot 1932: 487, pl. 17, figs 7-10.

Lacazella mediterranea - Pajaud 1970: 128, text-figs 50, 52, pl. 1, fig. 4, pl. 5, fig. 4, pl. 7, fig. 3, pl. 10, figs 1-6, pl. 11, fig. 3, pl. 12, fig. 2, pl. 16. - Logan 1979: 73, text-fig. 22, pl. 10, figs 1-8. - Taddei Ruggiero 1985: 376, 377. - Álvarez \& Emig 2005: 117-119, fig. 34AC. - Bitner \& Dieni 2005: 109, 110, fig. 4I-K. - Bitner \& Dulai 2008: 40, fig. 5.7-8. - Dulai 2010a: 28, pl. 3, fig. 3a, b.

Material eXAmined. - Peyrère: 306 complete specimens, 105 ventral and 72 dorsal valves, MNHN.F.A46537-A46543 and A46552. - Abesse: 97 complete specimens, 104 ventral and 47 dorsal valves MNHN. F.A46544-A46547, A46554 and A46556. - Estoti: four ventral valves, MNHN.F.A46548. - Bélus: one complete specimen, one ventral and one dorsal valves, MNHN.F.A46549. - Bezoye: ten complete specimens, 22 ventral and 12 dorsal valves, MNHN.F.A46550. Escornebéou: 17 ventral valves, Larralde Collection.

OCCURRENCE. - The stratigraphical range of this species is from the Upper Paleocene (Pajaud \& Plaziat 1972) to Recent. Its Recent representatives are living in the south-western part of the Mediterranean Sea at the depth of 1-110 m (Logan 2007) and are regarded as a neoendemic species (Logan et al. 2004). It is in fact a relict distribution because in the Eocene it is recorded throughout Europe but in the Neogene it is known only from the Mediterranean region.

\section{REMARKS}

This species dominates in the studied assemblage and is represented by more than 800 specimens. Its presence was already reported from the Oligocene of the Aquitaine Basin (Peyrot 1932; Pajaud 1974; Lozouet 2004).
TABLE 9. - Measurements (in $\mathrm{mm}$ ) of Lacazella mediterranea (Risso, 1826).

\begin{tabular}{lccc}
\hline Locality & Length & Width & Thickness \\
\hline Peyrère & 10.1 & 6.7 & 5.4 \\
Peyrère & 9.2 & 6.5 & 4.2 \\
Peyrère & 8.5 & 6.8 & 5.4 \\
Peyrère & 8.5 & 6.3 & 4.5 \\
Peyrère & 8.4 & 7.2 & 4.4 \\
Peyrère & 8.1 & 6.4 & 4.0 \\
Abesse & 3.8 & 3.1 & 2.1 \\
\hline
\end{tabular}

Although consistent with the hitherto described specimens (see Pajaud 1970; Logan 1979; Álvarez \& Emig 2005) the specimens from southern France are much larger, reaching about $10 \mathrm{~mm}$ of length, thus being even three times as long as those living today, which rarely exceed 3 mm (Logan 1979; Álvarez \& Emig 2005). The shell is variable in outline, usually subtriangular, with large interarea and wide, triangular pseudodeltidium. The hemispondylium takes the form of two prominent prongs and is supported by a small median septum (Fig. 9E). The cardinal process is large and subrectangular, extending beyond the margin. The median septum is divided forming a trifurcating structure, and the margins of interbrachial lobes are denticulated (Fig. 9G-L).

\section{PALEOECOLOGICAL REMARKS}

The Brachiopoda are very abundant in the marls of Peyrère and calcareous sands of Abesse but are scarcely represented in the other five outcrops (Fig. 1). From an ecological point of view the outcrops of the Upper Oligocene of the Aquitaine Basin can be divided into four main groups (Lozouet 2004): a shallow-water calcareous facies outcropping in the vicinity of Dax (Abesse, Bezoye, Estoti), a muddy sand assemblages (Escornebéou, Bélus), a mud assemblage localized in the paleocanyon and the Peyrère fauna. The shallow-water calcareous facies contains numerous faunistic elements of the littoral zone indicating the proximity of the shore line; otherwise the assemblage is particularly rich in macro-fossils (molluscs, hermatypic corals, bryozoans, serpulids). The muddy sand assemblages are characteristic of the sublittoral zone 
TABLE 10. - Drill hole data for the Upper Oligocene brachiopods from the Aquitaine Basin.

\begin{tabular}{lccccc}
\hline Species & $\begin{array}{c}\text { Number } \\
\text { undrilled }\end{array}$ & $\begin{array}{c}\text { Number drilled } \\
\text { (\% drilled) }\end{array}$ & $\begin{array}{c}\text { Drilled on } \\
\text { ventral }\end{array}$ & $\begin{array}{c}\text { Drilled on } \\
\text { dorsal }\end{array}$ & $\begin{array}{c}\text { Drilled on } \\
\text { both valves }\end{array}$ \\
\hline Novocrania anomala (Müller, 1776) & 12 & $0(0.0 \%)$ & 0 & 0 & 0 \\
Terebratulina retusa (Linnaeus, 1758) & 101 & $8(7.3 \%)$ & 3 & 5 & 0 \\
Megathiris detruncata (Gmelin, 1791) & 401 & $25(5.4 \%)$ & 6 & 18 & 1 \\
Argyrotheca cuneata (Risso, 1826) & 15 & $0(0.0 \%)$ & 0 & 0 & 0 \\
Argyrotheca bitnerae Dulai, 2011 & 56 & $0(0.0 \%)$ & 0 & 0 & 0 \\
Joania cordata (Risso, 1826) & 36 & $1(2.8 \%)$ & 1 & 0 & 0 \\
Joania peyrerensis n. sp. & 4 & $1(20 \%)$ & 0 & 1 & 0 \\
Megerlia truncata (Linnaeus, 1767) & 7 & $0(0.0 \%)$ & 0 & 0 & 0 \\
Lacazella mediterranea (Risso, 1826) & 775 & $24(3.0 \%)$ & 5 & 18 & 1 \\
\hline Totals & 1407 & $59(4.0 \%)$ & 15 & 42 & 2 \\
\hline
\end{tabular}

up to the depth of $80 \mathrm{~m}$ as indicated by the presence of gastropods with bathyal habitats: Seguenziidae Verrill, 1884, Benthonella Dall, 1889, Benthonellania Lozouet, 1990 (Lozouet 1990). The mud assemblages correspond to the distal part of the shelf and the top of the continental slope. The Peyrère fauna deserves special explanation. The originality of the Peyrère associated fauna, including gastropods, bivalves, annelids, corals with a very common species of the genus Epiphaxum Lonsdale, 1850 (Octocorallia) (Lozouet \& Molodtsova 2008), is clearly in abundance of elements characteristic for hard substrates and cryptic habitats (Lozouet 2004). Otherwise there are very characteristic forms, restricted today only to the submarine cave environments. The gastropod families Neritopsidae Gray, 1847, Neritiliidae Schepman, 1908 and Pickworthiidae Iredale, 1917 are the most emblematic. The micromorphic megathyridid and thecideide brachiopods commonly occur together, both today and in the fossil record (Meile \& Pajaud 1971), in shallow-water, tropical and subtropical environments (Logan 2005, 2008; Lüter et al. 2008). The thecideides display the greatest density in light-poor, cryptic habitats as overhangs, crevices, caves and subreef tunnels (Lee \& Robinson 2003; Logan 2004). Thus, their abundance in the Peyrère assemblage supports the earlier interpretations of the whole fauna as a cave biocenosis. In turn, the protected, stable environments of cryptic habitats may explain much larger size of Lacazella mediterranea from Peyrère than hitherto reported for this species.

\section{DRILLING PREDATION}

Gastropod predation intensity, with only few exceptions (see e.g., Baumiller \& Bitner 2004; Baumiller et al. 2006), is usually very low in most Cenozoic brachiopod populations (Taddei Ruggiero \& Bitner 2008), as here. Among 1466 specimens examined 59 specimens (4.0\%) were drilled (see Table 10). Such a low frequency may be explained by the fact that brachiopods are not the prime target where molluscs are very abundant. Drillings were observed on Terebratulina retusa, Megathiris detruncata, Joania cordata, J. peyrerensis n. sp. and Lacazella mediterranea. No drilling predation was observed on $\mathrm{No}$ vocrania anomala, Argyrotheca cuneata, A. bitnerae or Megerlia truncata. Taxonomic selectivity for particular species is difficult to explain and does not depend on amount of specimens. Drill holes were found on ventral and dorsal valves but the dorsal valve was drilled at a higher frequency (see Table 10); in two specimens drill holes occur on both valves (Fig. 10).

Drill holes on calcareous exoskeletons are for the most part due to two families of gastropods: Naticidae Guilding, 1834 and Muricidae Rafinesque, 1815 (Carriker \& Yochelson 1968). Drilling predation is known also in the scavenger family Nassariidae Iredale, 1916 (but it is exceptional) and in the Cassidae Latreille, 1825, which feed exclusively upon echinoderms (Riedel 1995). Naticidae and Muricidae are widespread in the Upper Oligocene of the Aquitaine Basin but the Naticidae are less common, being infaunal gastropods more common 


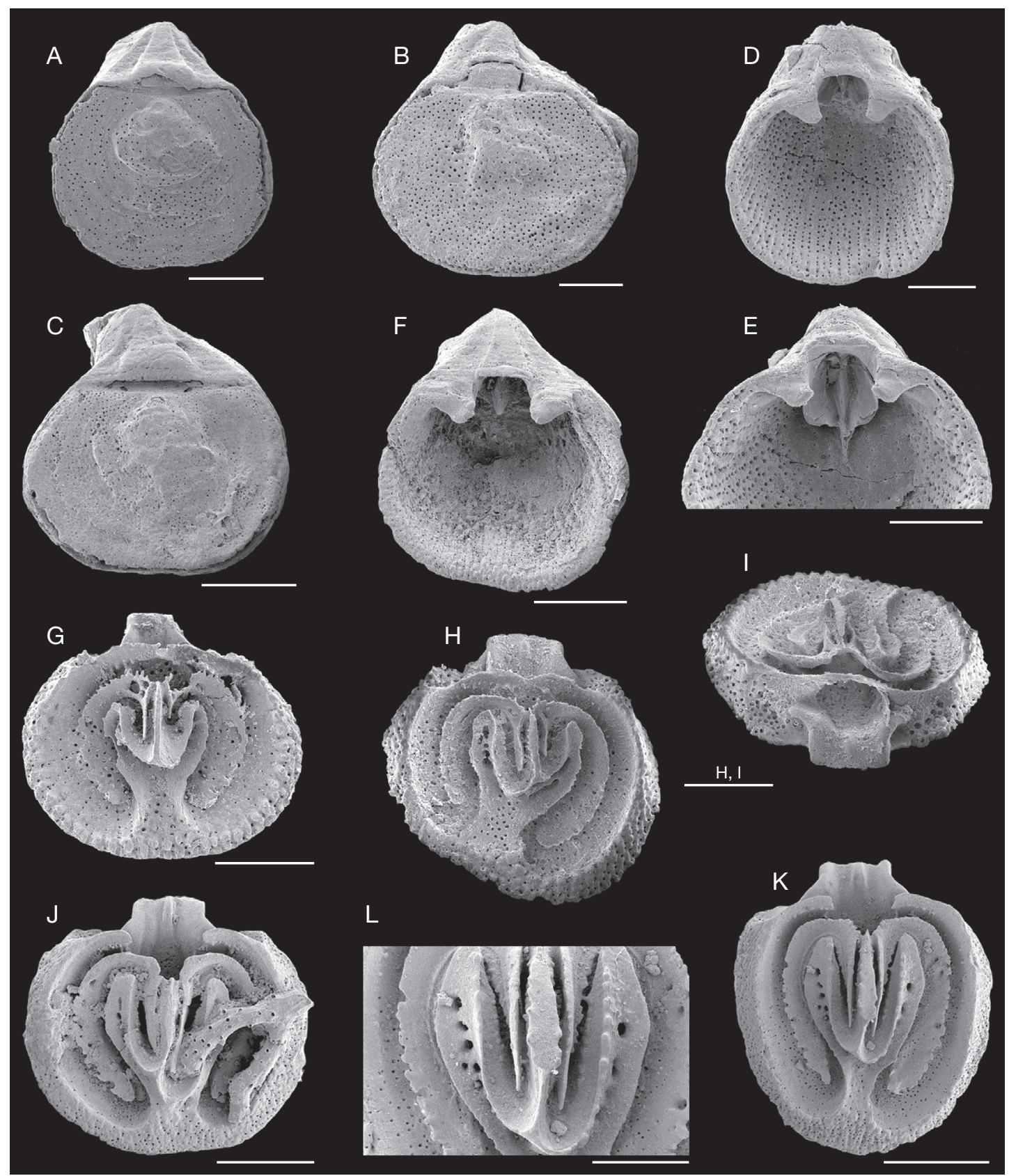

FIG. 9. - Lacazella mediterranea (Risso, 1826), Upper Oligocene: A-C, dorsal views of complete specimens: A, C, Peyrère, MNHN.F.A46537-A46538; B, Abesse, MNHN.F.A46544; D, E, inner view of ventral valve and tilted enlargement (E) to show hemispondylium, Abesse, MNHN.F.A46545; F, inner view of ventral valve, Peyrère, MNHN.F.A46539; G, inner view of dorsal valve, Abesse, MNHN.F.A46546; H, I, inner and posterior views of dorsal valve, Peyrère, MNHN.F.A46540; J, inner view of dorsal valve, Peyrère, MNHN.F.A46541; K, L, inner view of dorsal valve and enlargement $(\mathbf{L})$ of the trifurcating median ramus-ramuli complex, Peyrère, MNHN.F.A46542. All SEM. Scale bars: A, B, D, E, G-I, L, 1 mm; C, F, J, K, 2 mm. 
in littoral sandy deposits. In the outcrop of Peyrère where the Brachiopoda are especially common and very well preserved a bulk sample has permitted us to obtain 413 species of gastropods (Lozouet 2004) including two species of Naticidae (36 specimens) and 19 species of Muricidae (133 specimens). The Muricidae generally feed upon sedentary epifaunal prey and the Naticidae only bore when the prey is buried in sediment.

It is possible to differentiate boreholes produced by Muricidae or by Naticidae based on morphological criteria. The bore hole of Naticidae is neat and circular with a wide conical shape while those of Muricidae are more irregular; the hole is also straight-sided, or tapers slightly inwards (Taylor 1970). The holes reported in the studied brachiopod shells correspond clearly to muricid attacks (Fig. 10A, D-L). This is in good agreement with ecology of brachiopods and muricids, and diversity of muricids in the Peyrère outcrop.

\section{STABLE ISOTOPE ANALYSIS}

Brachiopods secrete a shell in oxygen isotopic equilibrium with surrounding seawater (Carpenter \& Lohmann 1995; Buening \& Spero 1996; Buening 2001; Brand et al. 2003). As their shell, composed of low-Mg calcite, is resistant to diagenesis they are good fossils for isotopic studies and are often used as a proxy for the environmental conditions of an ancient ocean (Brand et al. 2011). Carbon isotopic equilibrium in brachiopod shells is still uncertain and needs further investigations (Buening 2001; Brand et al. 2003).

For isotope analysis the three most abundant taxa in the studied species assemblage were chosen, Terebratulina retusa, Megathiris detruncata and Lacazella mediterranea. Under a scanning electron microscope (SEM) their shells appear to be very well preserved, suggesting that this material is suitable for istopic studies. The $\delta^{18} \mathrm{O}$ values of $M$. detruncata range from -0.41 to $-0.03 \%$ PDB (mean $-0.24 \%$ PDB), of $L$. mediterranea from -2.70 to $0.07 \%$ PDB (mean $-1.29 \%$ PDB) and of $T$. retusa from -0.55 to $-0.25 \%$ o PDB (mean $-0.40 \%$ PDB). The $\delta^{13} \mathrm{C}$ values of $M$. detruncata range from -0.82 to $2.55 \%$ PDB (mean $1.27 \%$ PDB), of $L$. mediterranea from -4.95 to $0.79 \%$ PDB (mean $-1.30 \%$ PDB) and of T. retusa from 1.09 to $1.66 \%$ o PDB (mean $1.37 \%$ PDB). Plots $\delta 18 \mathrm{O}$ versus $\delta 13 \mathrm{C}$ values for those species are shown in the Fig. 11. The results display substantial variability, with five samples of $L$. mediterranea having clearly more negative values than other samples. As both species, $M$. detruncata and $L$. mediterranea live in similar ecological conditions, possible explanations of those large differences in the isotopic values can comprise unrecognized diagenetic effects, different skeletal ultrastructures or vital effects. $\delta 13 \mathrm{C}$ values can be additionally affected by dissolved inorganic carbon. Nevertheless, a major difference in $\delta 13 \mathrm{C}$ values in co-occurring brachiopod species was already reported (Buening et al. 1998).

The shell in thecideide brachiopods is composed almost entirely of the microgranular primary layer. In the shell of terebratulides the primary layer constitutes a thin, outer layer, while the fibrous secondary layer dominates and this latter layer incorporates oxygen in isotopic equilibrium with the ambient seawater (Carpenter \& Lohmann 1995; Buening 2001; Brand et al. 2003). The primary layer is considered to be precipitated out of the equilibrium with the seawater (Carpenter \& Lohmann 1995; Buening 2001), however, Brand et al. (2003) in their detailed work on geochemistry of modern brachiopods concluded that the Thecideida, although built of the primary layer, incorporate oxygen isotopes in equilibrium with the ambient sea water. In turn, vital effects refer to the fact that some organisms may biologically control the incorporation of isotopes into skeletal calcium carbonate, thus precipitating shells in isotopic disequilibrium with surrounding seawater. These preliminary results of isotopic analyses are difficult to interpret at the moment and more studies, especially investigation of diagenetic effects, are necessary.

Nevertheless, we used the $\delta^{18} \mathrm{O}$ values of $M$. detruncata and T. retusa to estimate paleotemperatures. The oxygen isotope data of carbonate shells can be used only if the oxygen isotope composition of the seawater is known. Today's seawater has a mean composition of $0 \%$ SMOW. In open 


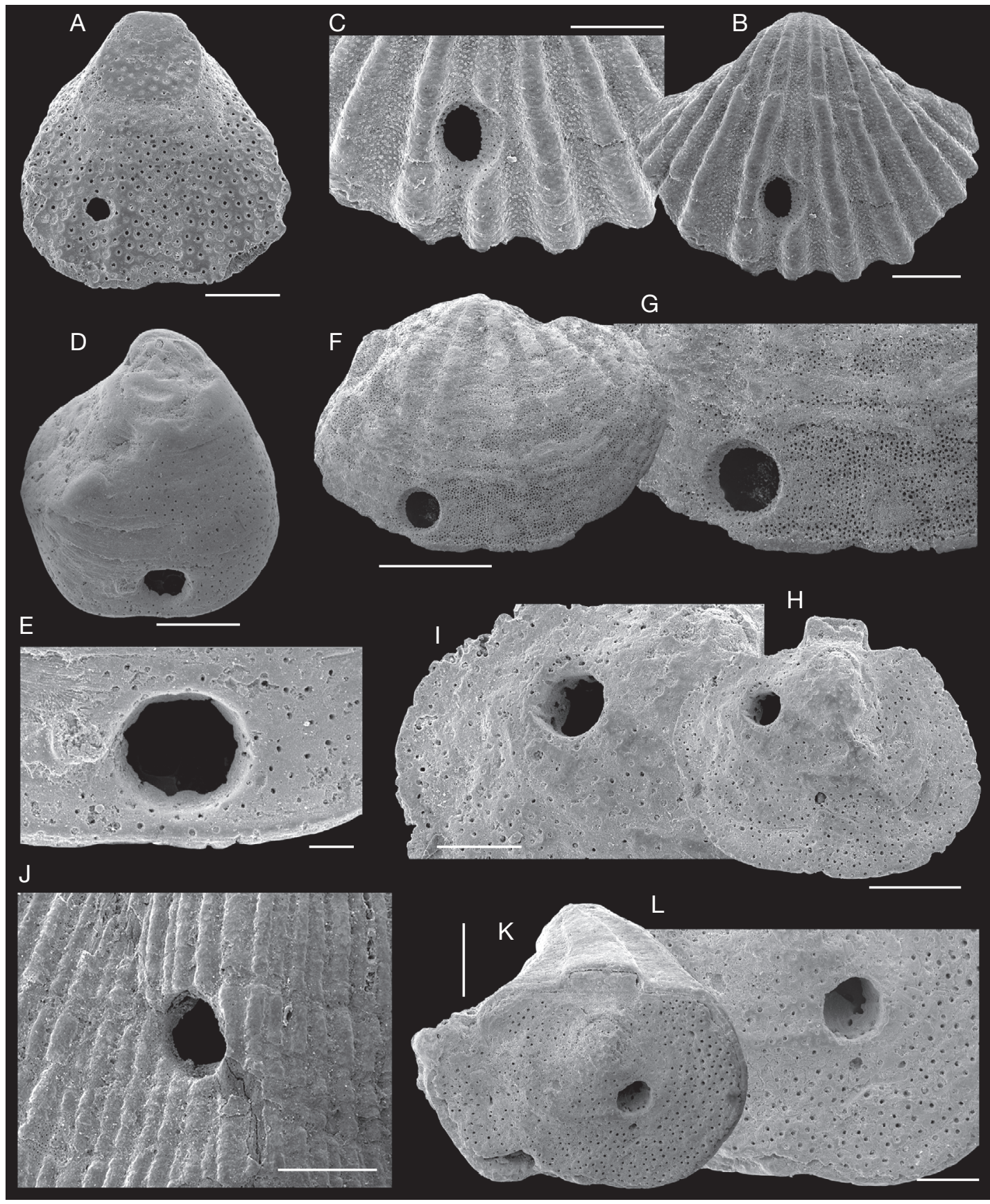

FIG. 10. - Examples of drilled brachiopods from the Upper Oligocene of the Aquitaine Basin, SW France: A, Joania cordata (Risso, 1826), ventral valve, Abesse, MNHN.F.A46551; B, C, Megathiris detruncata (Gmelin, 1791), ventral valve and a close-up image of drill hole, Bélus, MNHN.F.A46506; D, E, Lacazella mediterranea (Risso, 1826), ventral valve and close-up of drill hole, Peyrère, MNHN.F.A46552; F, G, M. detruncata, dorsal valve and close-up of drill hole, Peyrère, MNHN.F.A46554; H, I, L. mediterranea, dorsal valve and close-up of drill hole, Abesse, MNHN.F.A46553; J, Terebratulina retusa (Linnaeus, 1758), dorsal valve, Peyrère, MNHN.F.A46555; K, L, L. mediterranea, dorsal view of complete specimen

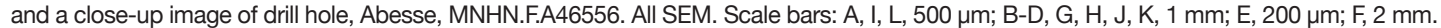


ocean environments the isotopic composition is controlled by global climate, however, in marginal seas or nearshore environments such factors as evaporation and/or freshwater input can change significantly the oxygen isotope value of seawater. Calculating temperatures with an assumed $\delta^{18} \mathrm{O}$ of $0 \%$ SMOW the results received show the range $17-19^{\circ} \mathrm{C}$. These results are too low and are in disagreement with the paleotemperatures obtained from the paleontological data; for the Upper Oligocene a subtropical to tropical climate is proposed (Lauriat-Rage et al. 1993; Lozouet 2004).

A similar discrepancy between temperatures obtained from paleontological and isotopic sources was observed by Latal et al. (2006) for the Middle Miocene sea of the Central Paratethys, thus they proposed for coastal environments the higher $\delta 18 \mathrm{O}$ value of $+1 \%$ o SMOW; this value is characteristic for the Mediterranean Sea, for instance. Using this value they obtained temperatures that fit well with other paleotemperature proxies.

Although the Upper Oligocene sea of the Aquitaine Basin cannot be compared with the epicontinental sea of the Central Paratethys, the Aquitaine Basin constituted during the Oligocene a narrow embayment, having character of marginal, nearshore environment with reduced exchange with the ocean. Thus, when assuming a value of $+1 \%$ SMOW for the Oligocene sea in the Aquitaine Basin the paleotemperatures calculated for $M$. detruncata vary from 21 to $23^{\circ} \mathrm{C}$, and for $T$. retusa from 22 to $24^{\circ} \mathrm{C}$. These temperatures fit much better with the paleoenvironmental interpretation based on faunal data. Because in marginal, nearshore marine settings the isotopic composition of seawater can be influenced by different factors (mostly evaporation and freshwater input) a combination of several independent methods, including isotopes, should be applied for a paleotemperature interpretation as presented by Latal et al. (2006) and Nehyba et al. (2008). In comparison, the higher $\delta 18 \mathrm{O}$ values (c. $1.1 \%$ PDB) of late Oligocene benthic foraminifera from the Deep Sea Drilling Project (DSDP) Site 119 in the Bay of Biscay (Miller \& Curry 1982; Miller 1983) point to a lower temperature that may be expected in more open ocean environment.

\section{CHARACTERISTICS OF BRACHIOPOD FAUNA AND ITS AFFINITIES}

The Upper Oligocene brachiopod fauna from the Aquitaine Basin, southwestern France that belongs to the Atlantic Province, contains nine species belonging to seven genera. They include both inarticulate and articulate brachiopods. Inarticulate brachiopods are represented by one cementing species, Novocrania anomala. Among articulate brachiopods there is one representative of the short-looped brachiopods, a member of the family Cancellothyridae, Terebratulina retusa. Also the families Kraussinidae and Thecideidae are represented by one species each, Megerlia truncata and Lacazella mediterranea, respectively. More diverse is the family Megathyrididae with five species recognized, namely Megathiris detruncata, two species of Argyrotheca, A. cuneata and A. bitnerae, and two species of Joania, J. cordata and J. peyrerensis n. sp. The latter species has been described as a new taxon. Two species, Megathiris detruncata and Lacazella mediterranea dominate in the studied assemblage, constituting more than $80 \%$ of the material. All species, except $M$. detruncata and $L$. mediterranea, are reported for the first time from this region; however, the presence of the genus Argyrotheca without specific attribution was already announced (Lozouet 2004). The occurrence in the studied assemblage of Novocrania anomala, Terebratulina retusa, Argyrotheca cuneata, A. bitnerae, Joania cordata, and Megerlia truncata extends the stratigraphical range of those species from the Miocene to the Oligocene. In the case of Joania and Megerlia there are the oldest occurrences of those genera.

The species composition in particular localities differs considerably. The most diverse localities are Peyrère and Bélus where nine and six species were found, respectively. It may be explained by the peculiarity of the paleoenvironment in the region of Peyrère and Bélus. Both outcrops are located near the head of the paleocanyon with abundance of hard substrates and cryptic habitats, suitable environment for megathyridid and thecideide brachiopods. The two localities of Escornebéou and St-Étienne-d'Orthe show the lowest diversity with one species only. In the region of Dax five species were recognized. 
The Chattian brachiopods contain one form potentially endemic to the Aquitaine Basin, J. peyrerensis $\mathrm{n}$. sp. and other species having wide stratigraphical and geographical range. In taxonomic composition the brachiopod fauna from the Aquitaine Basin displays low affinity with preceding Eocene faunas (e.g. Davidson 1870; Fabiani 1913; Calzada et al. 1988; Bitner 2000; Bitner \& Dieni 2005; Bitner \& Dulai 2008; Dulai et al. 2010; Dulai 2011; Bitner et al. 2011); only two species, $M$. detruncata and $L$. mediterranea are in common. In the Eocene, like the Oligocene, megathyridids dominate, with $M$. detruncata and numerous species of Argyrotheca represented, however, by different species than those in the Oligocene. There are also few species of craniid brachiopods, rhynchonellides represented by the genera Erymnaria Cooper, 1959 and Streptaria Cooper, 1959, and shortlooped terebratulides like Gryphus and Leymerithyris Calzada, 1988. Restricted to the Eocene seemed to be two micromorphic cancellothyrids, Terebratulina tenuistriata (Leymerie, 1846) and Orthothyris pectinoides (von Koenen, 1894), however, recently the latter species has been found in the Lower Oligocene deposits of eastern Germany (Müller 2011b).

In turn, there is a great resemblance of the investigated brachiopod fauna to the Miocene faunas of the Mediterranean Province and Central Paratethys. Apart from J. peyrerensis n. sp., all species described here are known from one or both of these regions (e.g., Davidson 1864, 1870; Dreger 1889; Zilch 1934; Julien 1940; Bărbulescu \& Rado 1984; Gaetani \& Saccà 1985; Marras \& Ventura 1985; Bitner 1990, 1993; Taddei Ruggiero 1994; Bitner \& Pisera 2000; Bitner \& Dulai 2004; Logan et al. 2004; Dulai 2007, 2010a; Bitner \& Schneider 2009). Lacazella mediterranea common in the Miocene of the Mediterranean region (Davidson 1864; Julien 1940; Pajaud 1974; Logan et al. 2004) was not found in the Central Paratethys. The only thecideide brachiopod recognized in the Paratethys was Thecidellina Thomson, 1915 from Bulgaria (Bitner 1993). Argyrotheca bitnerae described originally from the Miocene of the Central Paratethys (Dulai \& Stachacz 2011) is recorded from the Oligocene of the Aquitaine Basin (this paper) but was not found in the Mediterranean province.

The low affinities to the Eocene brachiopod faunas may be explained by the dramatic changes in the

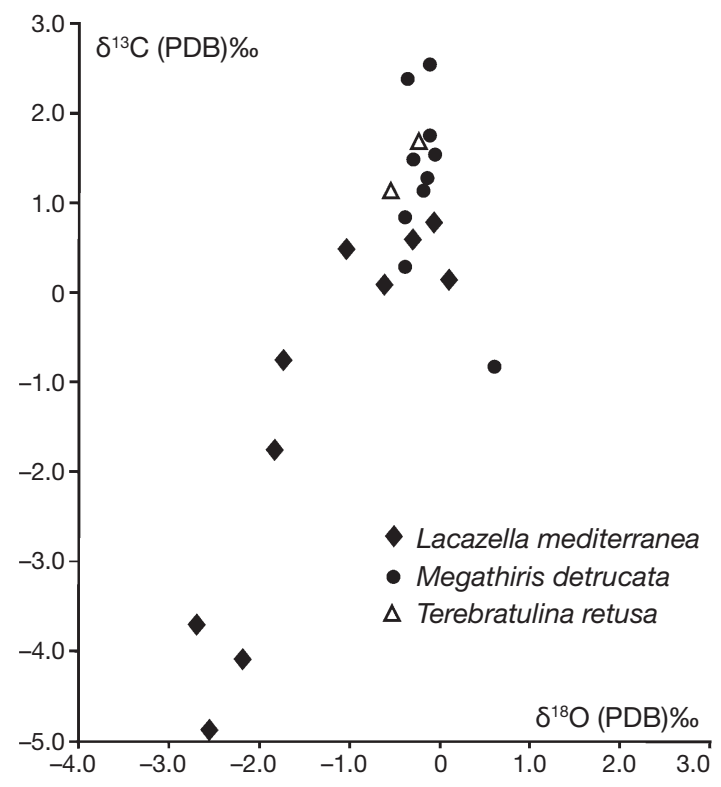

FIG. 11. - Stable carbon and oxygen isotopic values from brachiopod samples.

paleogeographical and paleoenvironmental conditions in Europe at the Eocene/Oligocene boundary, provoked by plate tectonic movements and formation of the Alpine chain (Meulenkamp \& Sissingh 2003; Ivany et al. 2003). In the earliest Oligocene the origin of the Paratethys began, and till the Middle Miocene two distinct basins, the Mediterranean Sea and the intercontinental Paratethys Sea in the North, existed. A drop of sea level and climatic cooling in the early Oligocene had a significant effect on a variety of most taxonomic groups (see Berggren \& Prothero 1992; Dockery \& Lozouet 2003); many forms became extinct and many new taxa appeared for the first time, and a similar pattern is visible among brachiopods. In the late Oligocene the climate again became warm (tropical to subtropical) and remained warm through the Miocene (Lauriat-Rage et al. 1993).

The Recent Mediterranean and Atlantic brachiopod faunas are clearly a continuation of those Oligocene-Miocene faunas as shown by the fact that seven of nine species described here are still living in the Mediterranean Sea and/or north-eastern Atlantic (Logan 1979, 1993, 2007; Logan et al. 2004; Álvarez \& Emig 2005). 


\section{Acknowledgements}

This research has been supported by a research grant No. N N307 129837 of the Ministry of Science and Higher Education of Poland to M. A. Bitner. K. Małkowski (Institute of Paleobiology, Warszawa) is thanked for isotope analyses and helpful discussions. Thanks are due to B. L. Cohen (University of Glasgow, Glasgow) for reading the manuscript, making useful comments and improving the English. We wish to thank A. Dulai (Hungarian Natural History Museum, Budapest), D. Huygues (IPRAUniversité de Pau et des Pays de l'Adour) and A. Ohler (Muséum national d'Histoire naturelle, Paris) for their comments and suggestions.

\section{REFERENCES}

Altichieri L. 1992. - Aggiornamento sulla fauna dei Brachiopodi delle Venezie. Memorie di Scienze Geologiche 46: 211-227.

Álvarez F. \& EMIG C. C. 2005. - Brachiopoda, in Lophophorata, Phoronida, Brachiopoda. Álvarez F., Emig C. C., Roldán C. \& Viéitez J. M., Fauna Iberica, vol. 27. Ramos M. A. et al. (eds). Museo Nacional de Ciencias Naturales, CSIC, Madrid: 57-177.

Álvarez F., Brunton C. H. C. \& Long S. L. 2008. Loop ultrastructure and development in recent Megathiridoidea, with description of a new genus, Joania (type species Terebratula cordata Risso, 1826), in CUSACK M. \& HARPER D. A. T. (eds), Brachiopod Research into the Third Millennium. Earth Environmental Science Transactions Royal Society Edinburgh 98: 391-403.

BĂRBUlesCU A. \& RADO G. 1984. - Contributions à la connaissance des brachiopodes badéniens de Roumanie. 75 years of the Laboratory of Paleontology, Special Volume: 173-183.

BARCZYK W. \& POPIEL-BARCZYK E. 1977. - Brachiopods from the Korytnica Basin (Middle Miocene; Holy Cross Mountains, Poland). Acta Geologica Polonica 27: 157-167.

Baumiller T. K. \& Bitner M. A. 2004. - A case of intense predatory drilling of brachiopods from the Middle Miocene of southeastern Poland. Palaeogeography, Palaeoclimatology, Palaeoecology 214: 85-95.

Baumiller T. K., Bitner M. A. \& Emig C. C. 2006. High frequency of drill holes in brachiopods from the Pliocene of Algeria and its ecological implications. Lethaia 39: 313-320.

Berggren W. A. \& Prothero D. R. 1992. — EoceneOligocene climatic and biotic evolution: an overview, in Prothero D. R. \& Berggren W. A. (eds), EoceneOligocene Climatic and Biotic Evolution. Princeton University Press, Princeton: 1-28.
Bitner M. A. 1990. — Middle Miocene (Badenian) brachiopods from the Roztocze Hills, south-eastern Poland. Acta Geologica Polonica 40: 129-157.

Bitner M. A. 1993. - Middle Miocene (Badenian) brachiopods from coral reefs of north-western Bulgaria. Acta Geologica Polonica 43: 147-155.

BitNer M. A. 2000. — Lower Eocene (Middle Ilerdian) brachiopods from the Campo region, Central Pyrenees, north-eastern Spain. Revista Española de Paleontología 15: 117-128.

Bitner M. A. 2008. - New data on the Recent brachiopods from the Fiji and Wallis and Futuna islands, South-West Pacific. Zoosystema 30: 419-461.

Bitner M. A. \& Pisera A. 2000. - Brachiopod fauna from the Middle Miocene deposits of Niechobrz, southeastern Poland. Tertiary Research 20: 7-15.

Bitner M. A. \& Moissette P. 2003. - Pliocene brachiopods from the north-western Africa. Geodiversitas 25 (3): 463-479.

Bitner M. A. \& Cahuzac B. 2004. - The genus Cryptopora (Brachiopoda) from the Miocene of France and its history and biogeography. Geobios 37: 1-12.

Bitner M. A. \& Dulai A. 2004. - Revision of Miocene brachiopods of the Hungarian Natural History Museum, with special regard to the Meznerics collection. Fragmenta Palaeontologica Hungarica 22: 69-82.

Bitner M. A. \& Kaim A. 2004. - The Miocene brachiopods from the silty facies of the intra-Carpathian Nowy Sącz Basin (Poland). Geological Quarterly 48: 193-198.

Bitner M. A. \& Dieni I. 2005. - Late Eocene brachiopods from the Euganean Hills (NE Italy). Eclogae Geologicae Helvetiae 98: 103-111.

Bitner M. A. \& Dulai A. 2008. - Eocene micromorphic brachiopods from the north-western Hungary. Geologica Carpathica 59: 31-43.

Bitner M. A. \& SChneider S. 2009. - The Upper Burdigalian (Ottnangian) brachiopod fauna from the northern coast of the Upper Marine Molasse Sea in Bavaria, Southern Germany. Neues Jahrbuch für Geologie und Paläontologie, Abhandlungen 254: 117-133.

BitNer M. A. \& KROH A. 2011. - First record of the genus Bronnothyris (Brachiopoda: Megathyrididae) from the Oligocene of the Mainz Basin, Germany. Geologica Carpathica 62: 203-209.

BitNer M.A. \& CAHUZAC B. 2013. - New record of Discradisca (Brachiopoda: Discinidae) from the Early Miocene of the Aquitaine Basin, south-western France. Comptes Rendus Palevol 12: 23-29.

Bitner M. A., Logan A. \& Gischler E. 2008. — Recent brachiopods from the Persian Gulf and their biogeographical significance. Scientia Marina 72: 279-285.

Bitner M. A., Dulai A. \& Galácz A. 2011. — Middle Eocene brachiopods from the Szőc Limestone Formation (Bakony Mountains, Hungary), with description of a new genus. Neues Jahrbuch für Geol- 
ogie und Paläontologie, Abhandlungen 259: 113-128.

Brand U., Logan A., Hiller N. \& Richardson J. 2003. - Geochemistry of modern brachiopods: applications and implications for oceanography and paleoceanography. Chemical Geology 198: 305-334.

Brand U., Logan A., Bitner M. A., Griesshaber E., Azmy K. \& BuHL D. 2011. - What is the ideal proxy of Paleozoic seawater chemistry? Memoirs of the Association of Australasian Palaeontologists 41: 9-24.

Brunton C. H. C. \& CURry G. B. 1979. - British brachiopods. Synopses of the British Fauna (New Series) 17: 1-64.

Brunton C. H. C., Cocks L. R. M. \& Dance S. P. 1967. - Brachiopods in the Linnaean Collection. Proceedings of the Linnean Society of London 178: 161-183.

BUENING N. 2001. - Brachiopod shells: recorders of the present and keys to the past, in CARLSON S. J. \& SANDY M. R. (eds), Brachiopods Ancient and Modern. The Paleontological Society Special Papers 7: 117-143.

Buening N. \& SPero H. J. 1996. - Oxygen- and carbon-isotope analyses of the articulate brachiopod Laques californianus. A recorder of environmental changes in the subeuphotic zone. Marine Biology 127: 105-114.

Buening N., Carlson S. J., Spero H. J. \& Lee D. E. 1998. - Evidence for the early Oligocene formation of a proto-subtropical convergence from oxygen isotope records of New Zealand Paleogene brachiopods. Palaeogeography, Palaeoclimatology, Palaeoecology 138: 43-68.

Cahuzac B. \& Poignant A. 1997. - Essai de biozonation de l'Oligo-Miocène dans les bassins européens à l'aide des grands foraminiferes néritiques. Bulletin de la Société géologique de France, Paris 168 (2): 155-169.

Cahuzac B., Janin M.-C. \& Steurbaut E. 1995. Biostratigraphie de l'Oligo-Miocène du bassin d'Aquitaine fondée sur les nannofossiles calcaires. Implications paléogéographiques. Géologie de la France 2: 57-79.

Calzada S., Seguier J. \& Tambareau Y. 1988. - Leymerithyris n. gen. montolearensis (Leymerie, 1846), brachiopode de l'Ilerdien circum-Pyrénéen. Implications chronostratigraphiques et paléoécologiques. Bulletin de la Société d'Etudes scientifiques de l'Aude 88: 37-44.

Carpenter S. J. \& Lohmann K. C. 1995. - $\delta^{18 O}$ and ${ }^{13} \mathrm{C}$ values of modern brachiopod shells. Geochimica Cosmochimica Acta 59: 3749-3764.

CARriker M. R. \& Yochelson E. L. 1968. — Recent gastropod boreholes and Ordovician cylindrical borings. U.S. Geological Survey, Professional Papers 593 (B): 1-26.

CoOper G. A. 1977. - Brachiopods from the Caribbean Sea and adjacent waters. Studies in Tropical Oceanography 14: 1-211.

CoOper G. A. 1981. - Brachiopods from the Southern Indian Ocean (Recent). Smithsonian Contributions to
Paleobiology 43: 1-93.

Curry G. B. 1982. - Ecology and population structure of the recent brachiopod Terebratulina from Scotland. Palaeontology 25: 227-246.

DALL W. H. 1900. - Some names which must be discarded. Nautilus 14 (4): 44-45.

Dall W. H. 1920. — Annoted list of the Recent Brachiopoda in the collection of the United States National Museum, with description of thirty-three new forms. Proceedings of the United States National Museum 57: 261-377.

DAVIDSON T. 1864. - Descriptions of the Brachiopoda, in Adams L., Outline of the geology of the Maltese Islands. The Annals and Magazine of Natural History series 3rd, 14: 1-11.

DAVIDSON T. 1870. — On Italian Tertiary Brachiopoda. Geological Magazine 7 (8-10): 359-370, 399-408, 460-466.

De Geyter G., De Man E., Herman J., Jacobs P., Moorkens T., Steurbaut E. \& Vandenberghe N. 2006. - Disused Paleogene regional stages from Belgium: Montian, Heersian, Landenian, Paniselian, Bruxellian, Laekenian, Ledian, Wemmlian and Tongrian, in Dejonghe L. (ed.), Current status of chronostratigraphic units named from Belgium and adjacent areas. Geologica Belgica 9: 203-213.

DOCKERY D. T. \& LOZOUET P. 2003. - Molluscan faunas across the Eocene/Oligocene boundary in the North American Gulf Coastal Plain, with comparisons to those of the Eocene and Oligocene of France, in Prothero D. R., Ivany L. C. \& Nesbitt E. A. (eds), From Greenhouse to Icehouse. The Marine Eocene-Oligocene Transition. Columbia University Press, New York: 303-340.

Dolin C., Dolin L. \& Lozouet P. 1985. — Paleoecology of some classic Tertiary localities in the Aquitaine and Paris Basins of France. Mississippi Geology 5: 4-13.

Dreger J. 1889. - Die tertiären Brachiopoden des Wiener Beckens. Beiträge zur Paläontologie OesterreichUngarns 7: 179-192.

DulaI A. 2007. — Badenian (Middle Miocene) micromorphic brachiopods from Bánd and Devecser (Bakony Mountains, Hungary). Fragmenta Palaeontologica Hungarica 24-25: 1-13.

Dulai A. 2010a. - Early Messinian (Late Miocene) micromorphic brachiopods from Borelli (Italy, Piemonte). Fragmenta Palaeontologica Hungarica 28: 21-31.

DulaI A. 2010b. - Palaeogene brachiopods from the Late Eocene of Austria and the Oligocene of Hungary, in Program \& Abstracts, $6^{\text {th }}$ International Brachiopod Congress, 1-5 February 2010, Melbourne, Australia. Geological Society of Australia, Abstracts 95: 38-39.

DUlaI A. 2011. - Late Eocene (Priabonian) micromorphic brachiopods from the Upper Austrian Molasse Zone. Memoirs of the Association of Australasian Palacontologists 41: 295-313. 
Dulai A. \& Stachacz M. 2011. — New Middle Miocene Argyrotheca (Brachiopoda; Megathyrididae) species from the Central Paratethys. Földtani Közlöny 141: 283-291.

Dulai A., Hradecká L., Konzalová M., Less G., ŠVÁBENICKÁ L. \& LoBITZER H. 2010. — An Early Eocene fauna and flora from "Rote Kirche" in Gschliefgraben near Gmunden, Upper Austria. Abhandlungen der Geologischen Bundesanstalt 65: 181-201.

Emig C. C., Bitner M. A. \& CahuzaC B. 2007. — First record of Lingula (Brachiopoda) from the Miocene of France, with diagnosis of L. dregeri. Comptes Rendus Palevol 6: 261-267.

FABIANI R. 1913. — I Brachiopodi terziari del Veneto. Memorie dell'Istituto Geologico della R. Università di Padova 2: 3-42.

GAETANi M. \& SACCÀ D. 1985. — Brachiopodi neogenici e pleistocenici della provincia di Messina e della Calabria meridionale. Geologica Romana 22 (1983): 1-43.

GMelin J. F. 1791. - Systema Naturae. 13 ed., Beer, Lipsiae: $3021-4120$.

Hiller N. 2011. — Micromorphic brachiopods from the Early Miocene (Otaian) of Northland, New Zealand. New Zealand Journal of Geology and Geophysics 54: 75-87.

Hiller N., Robinson J. H. \& LeE D. E. 2008. - The micromorphic brachiopod Argyrotheca (Terebratulida: Megathyridoidea) in Australia and New Zealand. Proceedings of the Royal Society of Victoria 120: 167-183.

Ivany L. C., Nesbitt E. A. \& Prothero D. R. 2003. The marine Eocene-Oligocene transition: a synthesis, in Prothero D. R., Ivany L. C. \& Nesbitt E. A. (eds), From Greenhouse to Icehouse. The Marine Eocene-Oligocene transition. Columbia University Press, New York: 522-534.

JuliEN M. 1940. — Révision de la faune vindobonienne de Saint-Fons (Rhône). Travaux du Laboratoire de Géologie de la Faculté des Sciences de Lyon 38: 1-60.

KIEKEN M. 1973. - Évolution de l'Aquitaine au cours du Tertiaire. Bulletin de la Société géologique de France (7) 15: 40-50.

KING W. 1850. - A monograph of the Permian Fossils of England. Palaeontographical Society Monograph 3: 1-258.

KoEnen A. vON 1894. - Das Norddeutsche UnterOligocän und seine Mollusken-Fauna. Abhandlungen zur geologischen Specialkarte von Preussen und den Thüringischen Staaten 10: 1250-1392.

KROH A. 2003. - The Brachiopoda of the Langhian (Lower Badenian) of the Molasse Zone and the northern Vienna Basin (Austria). Annalen des Naturhistorischen Museums in Wien 104A: 145-153.

Latal C., Piller W. E. \& Harzhauser M. 2006. Shifts in oxygen and carbon isotope signals in marine molluscs from the Central Paratethys (Europe) around the Lower/Middle Miocene transition. Palaeogeo- graphy, Palaeoclimatology, Palaeoecology 231: 347-360. Lauriat-Rage A., Brébion P., Cahuzac B., Chaix C., Ducasses O., Ginsburg L., Janin M.-C., Lozouet P., Margerel J.-P., Nascimento A., Pais J., Poignant A., Pouyet S. \& Roman J. 1993. - Palaeontological data about the climatic trends from Chattian to present along the Northeastern Atlantic frontage. Ciências da Terra 12: 167-179.

LeE D. E. \& BRUnTON C.H.C. 1986. - Neocrania n. gen., and a revision of Cretaceous-Recent brachiopod genera in the family Craniidae. Bulletin of the British Museum (Natural History), Geology 40: 141-160.

LeE D. E. \& Robinson J. H. 2003. - Kakanuiella (gen. nov.) and Thecidellina: Cenozoic and Recent thecideide brachiopods from New Zealand. Journal of the Royal Society of New Zealand 33: 341-361.

LiNNAEUS C. 1758. - Systema Naturae per Regna tria Naturae,secudum classes, ordines, genera, species. 10th edition. Holmiae, Stockholm: 823 p.

LiNNAEUS C. 1767. - Systema Naturae, sive Regna tria Naturae systematicae proposita per Classes, Ordines, Genera et Species. 12th edition. Holmiae, Stockholm: 533-1327.

LOGAN A. 1979. — The Recent Brachiopoda of the Mediterranean Sea. Bulletin de l'Institut Océanographique Monaco 72: 1-112.

LOGAN A. 1983. — Brachiopoda collected by CANCAP I-III expeditions to the south-east North Atlantic. 1976-1978. Zoologische Mededelingen 57: 165-189.

LOGAN A. 1988. - Brachiopoda collected by CANCAP IV and VI expeditions to the south-east North Atlantic. 1980-1982. Zoologische Mededelingen 62: 59-71.

LoGAN A. 1993. - Recent brachiopods from the Canarian-Cape Verdean region: diversity, biogeographic affinities, bathymetric range and life habits. Courier Forschungs-Institut Senckenberg 159: 229-233.

LOGAN A. 1998. - Recent Brachiopoda from the oceanographic expedition SEAMOUNT 2 to the north-eastern Atlantic in 1993. Zoosystema 20 (4): 549-562.

LoGAN A. 2004. - Ecological, Reproductive and Ontogenetic Features in Pajaudina atlantica Logan (Thecideidae, Brachiopoda, Recent) from the Canary Islands. Marine Ecology 25: 207-215.

LOGAN A. 2005. - A new lacazelline species (Brachiopoda, recent) from the Maldive Islands, Indian Ocean. Systematics and Biodiversity 3: 97-104.

LOGAN A. 2007. - Geographic distribution of extant articulated brachiopods, in SELDEN P. A. (ed.), Treatise on Invertebrate Paleontology. Part H. Brachiopoda Revised. Volume 6. Geological Society of America and University of Kansas, Boulder, Colorado and Lawrence, Kansas: 3082-3115.

LOGAN A. 2008. - Holocene thecideide brachiopods from the north-western Pacific Ocean: systematics, life habits and ontogeny. Systematics and Biodiversity 6: 405-413. 
LOGAN A. \& LONG S. L. 2001. — Shell morphology and geographical distribution of Neocrania (Brachiopoda, Recent) in the eastern North Atlantic and Mediterranean Sea, in BRunTON C. H. C., Cocks L. R. M. \& LONG S. L. (eds), Brachiopods Past and Present. Systematics Association, Special Volume Series 63: 71-79.

Logan A., Bianchi C. N., Morri C. \& Zibrowius H. 2004. - The present-day Mediterranean brachiopod fauna: diversity, life habits, biogeography and paleobiogeography, in Ros J. D., PACKARD T. T., GILI J. M., Pretus J. L. \& Blasco D. (eds), Biological oceanography at the turn of the Millenium. Scientia Marina 68 (Suppl. 1): 163-170.

LozoueT P. 1990. - Benthonellania nouveau genre de Rissoidae (Gastropoda, Prosobranchia) du bathyal atlantique. Bulletin du Muséum national d'Histoire naturelle, Paris, 4e série, 12, section A, 2: 313-328.

LozoueT P. 2004. - The European Tertiary Neritiliidae (Mollusca, Gastropoda, Neritopsina): indicators of tropical submarine cave environments and freshwater faunas. Zoological Journal of the Linnean Society 140: 447-467.

Lozouet P. \& Molodtsova T. 2008. — Filling a gap: the first occurrences of Epiphaxum (Cnidaria: Helioporacea: Lithotelestidae) in the Eocene, Oligocene and Miocene. Palaeontology 51 (1): 241-250.

Lüter C., Hoffmann J. \& Logan A. 2008. - Cryptic speciation in the Recent thecideide brachiopod Thecidellina in the Atlantic and the Caribbean. Earth and Environmental Science Transactions of the Royal Society of Edinburgh 98: 405-413

MANDRUZZATO F. 1970. - Nota di aggiornamento sui macrofossili oligocenici di Laverda. Atti e Memorie dell'Accademia Patavina di Scienze 82: 167-270.

Marras G. \& Ventura G. 1985. - Nota su alcuni brachiopodi miocenici di Florinas. Bollettino della Società Sarda di Scienze Naturali 24: 27-35.

Meile B. \& Pajaud D. 1971. - Présence de Brachiopodes dans le Grand Banc des Bahamas. Comptes Rendus Hebdomadaires des Séances de l'Académie des Sciences Paris, Série D, 273: 469-472.

Meulenkamp J. E. \& Sissingh W. 2003. - Tertiary palaeogeography and tectonostratigraphic evolution of the Northern and Southern Peri-Tethys platforms and the intermediate domains of the African-Eurasian convergent plate boundary zone. Palaeogeography, Palaeoclimatology, Palaeoecology 196: 209-228.

MEZNERICS I. 1944. - Die Brachiopoden des ungarischen Tertiärs. Annales historico-naturales Musei nationalis bungarici 36: 10-60

MiLler K. G. 1983. — Eocene-Oligocene paleoceanography of the deep Bay of Biscay: benthic foraminiferal evidence. Marine Micropaleontology 7: 403-440.

Miller K. G. \& Curry W. B. 1982. - Eocene to Oligocene benthic foraminiferal isotopic record in the Bay of Biscay. Nature 296: 347-350.
Munier-Chalmas E. P. 1880. — Note sommaire sur les genres de la famille des Thecideidae. Bulletin de la Société géologique de France (série 3) 8: 279-280.

Müller A. 2011a. - Der Steinbruch Mammendorf NW Magdebur - ein Felslitoral der unteroligozänen Nordsee. Geologica Saxonica 57: 3-120.

MüLler A. 2011b. - Paleogene of the Leipzig Embayment. Field Guide Excursion 1: 1-18; GV \& Sediment Meeting, Leipzig 2011.

MÜLler O. F. 1776. - Zoologiae Danicae prodromus, seu animalium Daniae et Norvegiae indigenarum characteres, nomina et synonyma imprimis popularium. Copenhagen, $282 \mathrm{p}$.

NehYBA S., ZÁGORŠEK K. \& Holcová K. 2008. - Stable isotope composition of bryozoan skeletons from Podbřežice (Middle Miocene, Central Paratethys, South Moravia, Czech Republic), in Hageman S. J., KeY M. \& Winston J. E. (eds), Bryozoan Studies 2007. Proceeding of the 14th International Bryozoology Association Conference, Boon, North Carolina. Virginia Museum of Natural History Special Publication Number 15: 163-175.

Pajaud D. 1970. - Monographie des Thécidées (Brachiopodes). Mémoires de la Société géologique de France (Nouvelle Série) 112: 1-349.

Pajaud D. 1974. - Biostratigraphie des Thécidées (Brachiopodes) données récentes ou inédites. Geobios 7: 323-344.

Pajaud D. \& Plaziat J.-C. 1972. - Brachiopodes thanétiens du synclinal sud-cantabrique au S-E de Vitoria (Pays basque espagnol). Étude systématique et interprétation paléoécologique. Bulletin de la Société d'Histoire naturelle de Toulouse 108: 446-473.

Peyrot A. 1932. - Conchologie néogénique de l'Aquitaine. Tom VI. Gastéropodes (fin), Ptéropodes, Céphalopodes, Brachiopodes. Actes de la Société Linnéenne de Bordeaux 84: 295-541.

Popiel-BARCZYK E. \& BARCZYK W. 1990. — Middle Miocene (Badenian) brachiopods from the southern slopes of the Holy Cross Mountains, Central Poland. Acta Geologica Polonica 40: 159-181.

RADWAŃSKA U. \& RADWAŃSKI A. 1989. - A new species of inarticulate brachiopods, Discinisca steiningeri sp. nov., from the Late Oligocene (Egerian) of Plesching near Linz, Austria. Annalen des Naturhistorischen Museums in Wien 90A: 67-82.

Riedel F. 1995. - An Outline of Cassidoidean Phylogeny (Molluscan, Gastropoda). Contributions to Tertiary and Quaternary Geology 32: 97-132.

Risso A. 1826. - Histoire naturelle des principales productions de l'Europe méridionale, et particulièrement de celles des environs de Nice et des Alpes maritimes. IV. F.-G. Levrault, Paris, 439 p.

SACCO F. 1902. - I Brachiopodi dei terreni terziarii del Piemonte e della Liguria. Clausen. Torino, 50 p.

Sandberger C. L. F. 1858-63. - Die Conchylien des Mainzer Tertiärbeckens. C.W. Kreidel's Verlag, 
Wiesbaden, 459 p., 35 pl. [Issued in parts: 1, 1-40, pls 1-5 (1858); 2, 41-72, pls 6-10 (1858); 3, 73-112, pls 11-15 (1859); 4, 113-152, pls 16-20 (1860); 5/6, 153-232, pls 21-30 (1861); 7, 233-270, pls 31-35 (1862); 8, 271-468 (1863)].

Simôes M. G., Kowalewski M., Mello L. H. C., Rodland D. L. \& Carroll M. 2004. - Recent brachiopods from the southern Brazilian shelf: palaeontological and biogeographical implications. Palaeontology 47: 515-533.

Simon E. 2010. - Argyrotheca furtiva n. sp. and Joania arguta (Grant, 1983) two micromorphic megathyrid brachiopods (Terebratulida, Megathyridoidea) from the Indonesian Archipelago. Bulletin de l'Institut royal des Sciences naturelles de Belgique, Biologie 80: 277-295.

TAddei Ruggiero E. 1985. - Paleoecologia e biostratigrafia delle calcareniti a brachiopodi di Castro (Lecce). Bollettino della Società dei Naturalisti in Napoli 92 (1983): 347-413.

TADDEI RUGGIERO E. 1993. - Argyrotheca ageriana sp. nov. (Brachiopoda): paleoecology and shell ultrastructure. Palaeogeography, Palaeoclimatology, Palaeoecology 100: 217-227.

TAddei Ruggiero E. 1994. - Neogene Salento brachiopod palaeocommunities. Bollettino della Società Paleontologica Italiana 33: 197-213.

TADDEI Ruggiero E. 1996. - Biostratigrafia e paleoecologia delle Calcareniti di Gravina nei dintorni di cerignola (brachiopodi e foraminiferi). Memorie della Società Geologica Italiana 51: 197-207.
Taddei Ruggiero E. \& Bitner M. A. 2008. — Bioerosion on the brachiopod shell. - a Cenozoic perspective, in Cusack M. \& Harper D. A. T. (eds), Brachiopod Research into the Third Millenium. Earth and Environmental Science Transactions of the Royal Society of Edinburgh 98: 369-378.

TAYLOR J. D. 1970. - Feeding habits of predatory gastropods in a Tertiary (Eocene) molluscan assemblage from the Paris Basin. Palaeontology 13 (2): 254-260.

ThOmson J. A. 1927. - Brachiopod morphology and genera (Recent and Tertiary). New Zealand Board of Science and Art, Manual 7:338 p.

Vail P. R., Mitchum R. M., Todd R. G., Widmier J. M., Thompson S. III, SAngree J. N., Bubb J. N. \& HatLelid W. G. 1977. - Seismic stratigraphy and global changes of sea level. American Association of Petroleum Geologists Memoir 26: 49-212.

Venzo S. 1941. - Fossili oligocenici della Valle del Maso (Valsugana). Studi Trentini di Scienze Naturali 22: $1-25$.

VINCENT E. 1893. — Contribution à la paléontologie des terrains tertiaires de la Belgique. Annales de la Société Royale Zoologique de Belgique 28: 38-64.

VINCENT E. 1923. — Quelques remarques sur des Brachiopodes tertiaires de Belgique et description d'une espèce nouvelle d'Argyrotheca. Annales de la Société Royale Zoologique de Belgique 53: 49-53.

ZiLCH A. 1934. - Zur Fauna des Mittel-Miocäns von Kostej (Banat); Typus Bistimmung und Tafeln zu O. Boettger's Bearbeitungen. Senckenbergiana 16: 193-302. 